Prepared in cooperation with the International Joint Commission

\title{
A Review of Surface Energy Balance Models for Estimating Actual Evapotranspiration with Remote Sensing at High Spatiotemporal Resolution over Large Extents
}

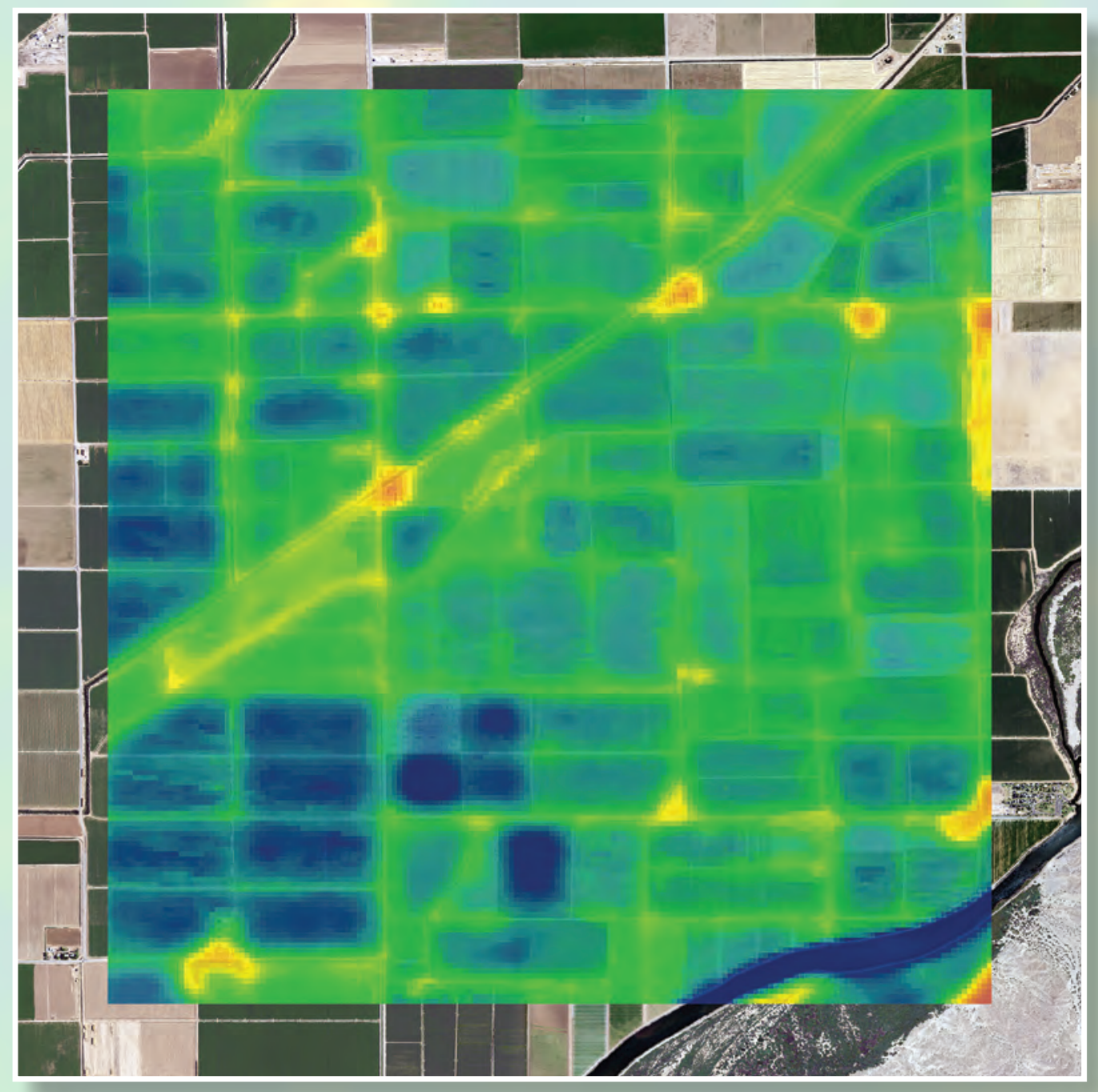

Scientific Investigations Report 2017-5087 
Cover. Aerial imagery of an irrigation district in southern California along the Colorado River with actual evapotranspiration modeled using Landsat data https://earthexplorer.usgs.gov; https://doi.org/10.5066/F7DF6PDR. 


\section{A Review of Surface Energy Balance Models for Estimating Actual Evapotranspiration with Remote Sensing at High Spatiotemporal Resolution over Large Extents}

By Ryan R. McShane, Katelyn P. Driscoll, and Roy Sando

Prepared in cooperation with the International Joint Commission

Scientific Investigations Report 2017-5087 


\title{
U.S. Department of the Interior \\ RYAN K. ZINKE, Secretary
}

\section{U.S. Geological Survey William H. Werkheiser, Acting Director}

\author{
U.S. Geological Survey, Reston, Virginia: 2017
}

For more information on the USGS - the Federal source for science about the Earth, its natural and living resources, natural hazards, and the environment-visit https://www.usgs.gov or call 1-888-ASK-USGS.

For an overview of USGS information products, including maps, imagery, and publications, visit https://store.usgs.gov.

Any use of trade, firm, or product names is for descriptive purposes only and does not imply endorsement by the U.S. Government.

Although this information product, for the most part, is in the public domain, it also may contain copyrighted materials as noted in the text. Permission to reproduce copyrighted items must be secured from the copyright owner.

Suggested citation:

McShane, R.R., Driscoll, K.P., and Sando, Roy, 2017, A review of surface energy balance models for estimating actual evapotranspiration with remote sensing at high spatiotemporal resolution over large extents: U.S. Geological Survey Scientific Investigations Report 2017-5087, 19 p., https://doi.org/10.3133/sir20175087.

ISSN 2328-0328 (online) 


\section{Contents}

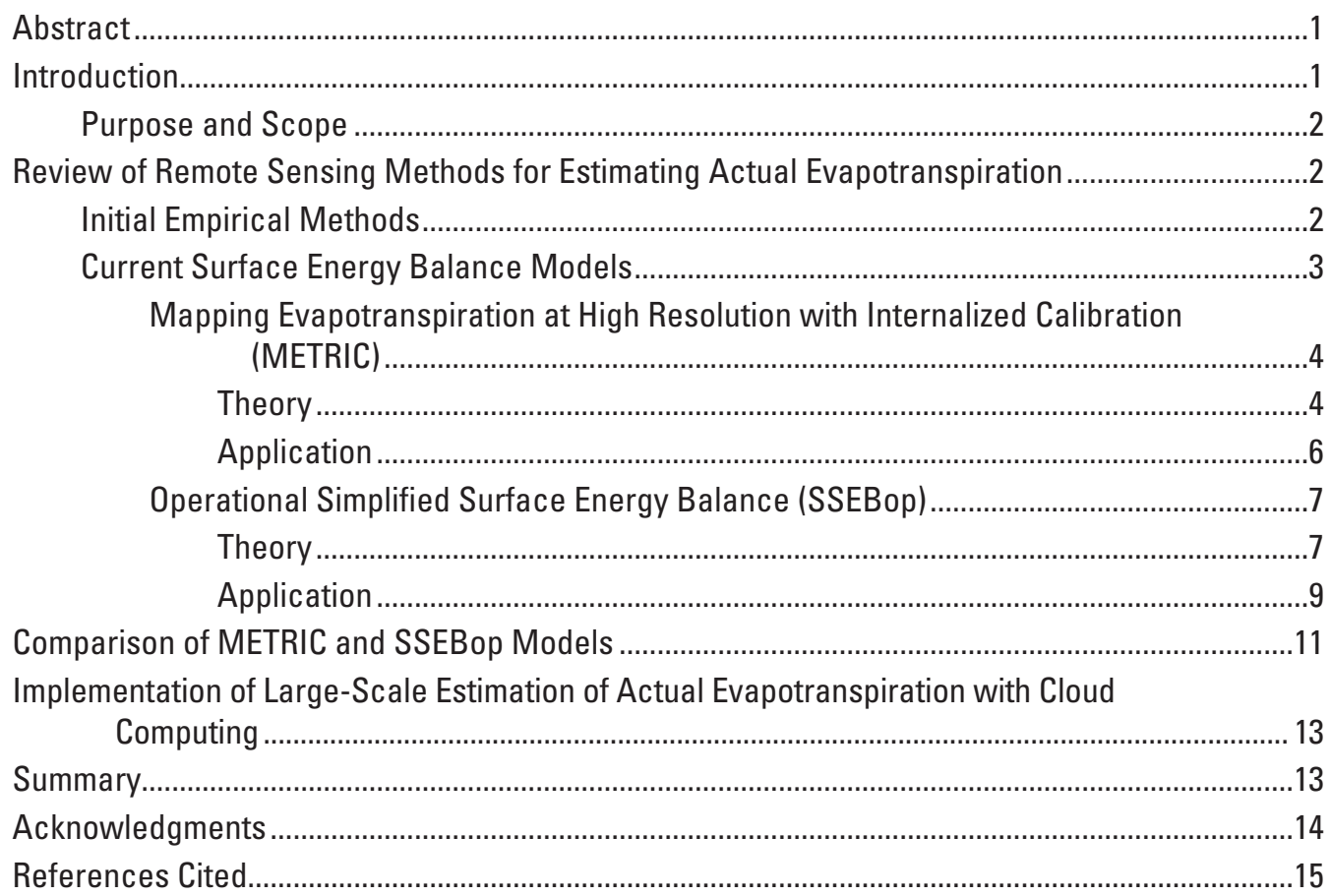

\section{Tables}

1. Comparison of the Mapping Evapotranspiration at High Resolution with Internalized Calibration and Operational Simplified Surface Energy Balance models 


\section{Conversion Factors}

International System of Units to U.S. customary units

\begin{tabular}{lcl}
\hline \multicolumn{1}{c}{ Multiply } & By & \multicolumn{1}{c}{ To obtain } \\
\hline millimeter $(\mathrm{mm})$ & Length & inch (in.) \\
meter $(\mathrm{m})$ & 0.03937 & foot $(\mathrm{ft})$ \\
kilometer $(\mathrm{km})$ & 3.281 & mile $(\mathrm{mi})$ \\
\hline & 0.6214 & \\
\hline hectare $(\mathrm{ha})$ & Area & acre \\
square kilometer $\left(\mathrm{km}^{2}\right)$ & 2.471 & square mile $\left(\mathrm{mi}^{2}\right)$ \\
\hline & 0.3861 & cubic mile $\left(\mathrm{mi}^{3}\right)$ \\
\hline cubic kilometer $\left(\mathrm{km}^{3}\right)$ & Volume & foot per hour $(\mathrm{ft} / \mathrm{hr})$ \\
\hline millimeter per hour $(\mathrm{mm} / \mathrm{h})$ & 0.2399 & \\
\hline & Flow rate & pound per cubic foot $\left(\mathrm{lb} / \mathrm{ft}^{3}\right)$ \\
\hline kilogram per cubic meter $\left(\mathrm{kg} / \mathrm{m}^{3}\right)$ & 0.003281 & kilowatthour $(\mathrm{kWh})$ \\
\hline joule $(\mathrm{J})$ & Density & 0.06242 \\
\hline
\end{tabular}

\section{Abbreviations}

$\alpha$

surface albedo

$\varepsilon_{0} \quad$ broadband surface thermal emissivity

$\lambda \quad$ latent heat of vaporization

$\rho_{\text {air }} \quad$ density of air

$\rho_{w} \quad$ density of water

ALEXI Atmosphere-Land Exchange Inverse

ASTER Advanced Spaceborne Thermal Emission and Reflection Radiometer

$C_{p} \quad$ specific heat of air at constant pressure

DEM digital elevation model

$d T \quad$ temperature difference between two near-surface heights (temperature gradient)

DTD Dual Temperature Difference

EF evaporative fraction

ET evapotranspiration

$E T_{0} \quad$ reference evapotranspiration

$E T_{a} \quad$ actual evapotranspiration

ETEML Enhanced Two-Source Evapotranspiration Model for Land

$E T_{f} \quad$ fractional evapotranspiration 


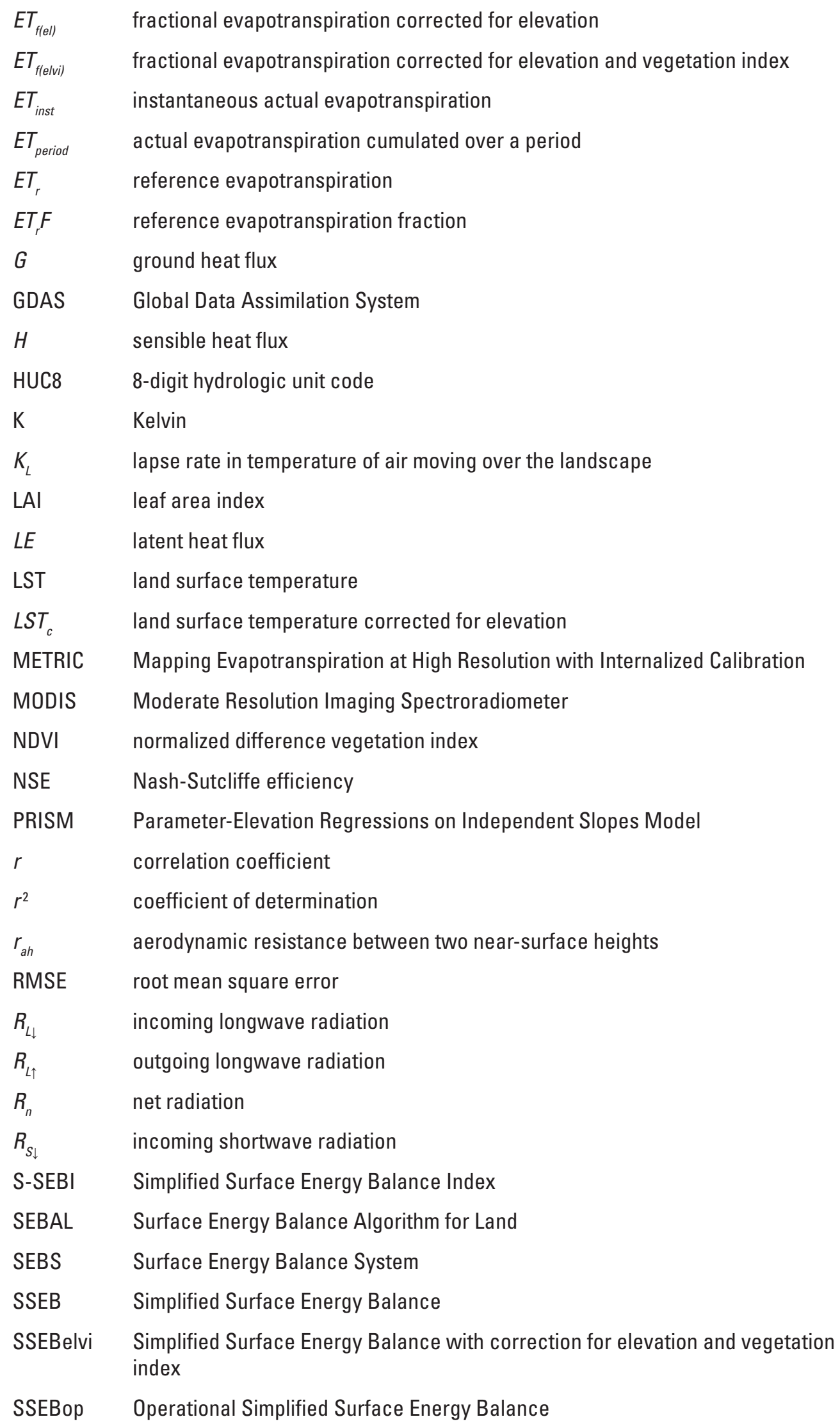




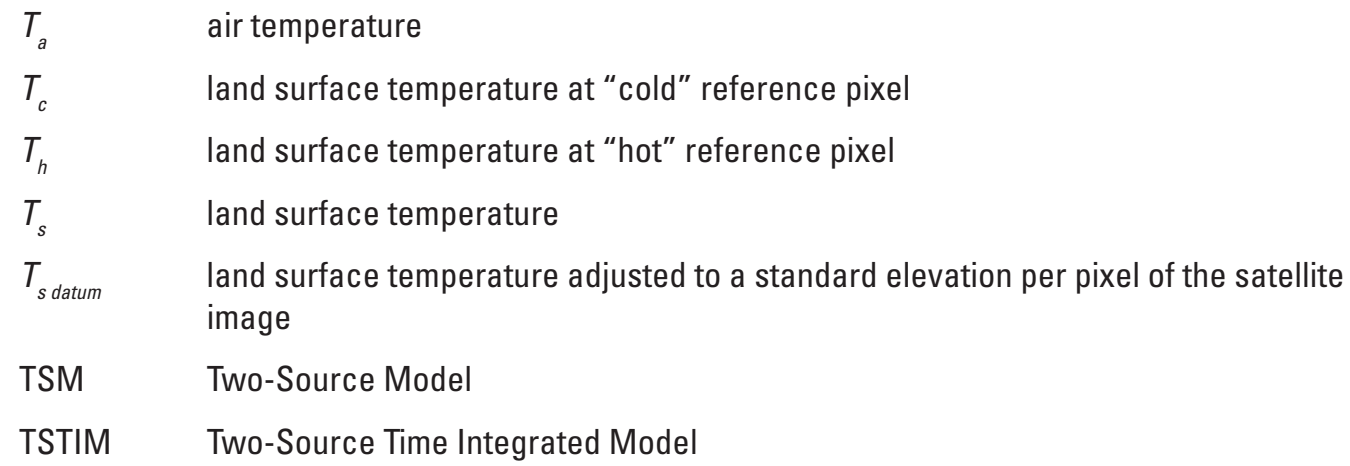




\title{
A Review of Surface Energy Balance Models for Estimating Actual Evapotranspiration with Remote Sensing at High Spatiotemporal Resolution over Large Extents
}

\author{
By Ryan R. McShane, Katelyn P. Driscoll, and Roy Sando
}

\section{Abstract}

Many approaches have been developed for measuring or estimating actual evapotranspiration $\left(E T_{a}\right)$, and research over many years has led to the development of remote sensing methods that are reliably reproducible and effective in estimating $E T_{a}$. Several remote sensing methods can be used to estimate $E T_{a}$ at the high spatial resolution of agricultural fields and the large extent of river basins. More complex remote sensing methods apply an analytical approach to $E T_{a}$ estimation using physically based models of varied complexity that require a combination of ground-based and remote sensing data, and are grounded in the theory behind the surface energy balance model. This report, funded through cooperation with the International Joint Commission, provides an overview of selected remote sensing methods used for estimating water consumed through $E T_{a}$ and focuses on Mapping Evapotranspiration at High Resolution with Internalized Calibration (METRIC) and Operational Simplified Surface Energy Balance (SSEBop), two energy balance models for estimating $E T_{a}$ that are currently applied successfully in the United States. The METRIC model can produce maps of $E T_{a}$ at high spatial resolution (30 meters using Landsat data) for specific areas smaller than several hundred square kilometers in extent, an improvement in practice over methods used more generally at larger scales. Many studies validating METRIC estimates of $E T_{a}$ against measurements from lysimeters have shown model accuracies on daily to seasonal time scales ranging from 85 to 95 percent. The METRIC model is accurate, but the greater complexity of METRIC results in greater data requirements, and the internalized calibration of METRIC leads to greater skill required for implementation. In contrast, SSEBop is a simpler model, having reduced data requirements and greater ease of implementation without a substantial loss of accuracy in estimating $E T_{a}$. The SSEBop model has been used to produce maps of $E T_{a}$ over very large extents (the conterminous United States) using lower spatial resolution (1 kilometer) Moderate Resolution Imaging Spectroradiometer (MODIS) data. Model accuracies ranging from 80 to 95 percent on daily to annual time scales have been shown in numerous studies that validated $E T_{a}$ estimates from SSEBop against eddy covariance measurements. The METRIC and SSEBop models can incorporate low and high spatial resolution data from MODIS and Landsat, but the high spatiotemporal resolution of $E T_{a}$ estimates using Landsat data over large extents takes immense computing power. Cloud computing is providing an opportunity for processing an increasing amount of geospatial "big data" in a decreasing period of time. For example, Google Earth Engine ${ }^{\mathrm{TM}}$ has been used to implement METRIC with automated calibration for regional-scale estimates of $E T_{a}$ using Landsat data. The U.S. Geological Survey also is using Google Earth Engine ${ }^{\mathrm{TM}}$ to implement SSEBop for estimating $E T_{a}$ in the United States at a continental scale using Landsat data.

\section{Introduction}

Consumptive water use refers to water that is evaporated and transpired from soils, vegetation, and open water (collectively called evapotranspiration [ET]); ingested by livestock and humans; or incorporated into crops and other commodities; and that consequently is unavailable for other demands on a water supply (Maupin and others, 2014). Most water consumption is through actual evapotranspiration $\left(E T_{a}\right)$, which is an important component of the water cycle, and it is estimated that about 70 percent of precipitation on land in the United States returns to the atmosphere through $E T_{a}$ (Carr and others, 1990). In addition, in the United States, more than 80 percent of water consumption is for agriculture (Carr and others, 1990), most of which is from $E T_{a}$. Therefore, water resource users and managers have a vested interest in accurately determining consumptive water use, especially when considering the effect of population growth and climate change on water demand and supply (Vörösmarty and others, 2000). Distribution of water resources depends on knowing the volume of water that initially is available for use and knowing how much 
of that water is consumed, thus making it unavailable for additional uses.

Many approaches have been developed for measuring or estimating $E T_{a}$, which constitutes a large fraction of consumptive water use (Allen and others, 2011b). The $E T_{a}$ at a site can be measured directly using lysimeters (Pruitt and Angus, 1960), eddy covariance flux towers (Swinbank, 1951), or scintillometers (Meijninger and others, 2002); however, using these instruments can involve substantial expense and effort and requires well-trained personnel. The $E T_{a}$ also can be measured indirectly at a site using evaporation pans (Snyder, 1992) or Bowen ratio stations (Fritschen, 1965). The use of these instruments, although requiring less expense and training than directly measuring $E T_{a}$, still entails considerable labor. Additionally, these direct and indirect measurements of $E T_{a}$ are limited to the sites and times at which they are taken.

A simple technique for estimating $E T_{a}$ over larger extents and longer time periods involves the use of crop coefficients (Allen and others, 1998). A crop coefficient is a factor that relates $E T_{a}$ of a plant to that of a reference state by parameterizing several characteristics of the plant and the soil. Crop coefficients have been developed for numerous plant species. This technique can be scaled to larger extents or longer time periods and transferred among sites because crop coefficients are fixed parameters, although a crop type may have several factors depending on the number of growth stages (for example, initial and development). Applying this technique more broadly, however, is difficult because of complications with determining crop types or growth stages from aerial photography or satellite imagery. Furthermore, this technique makes a questionable assumption that local conditions affecting parameters are spatially homogenous. Despite these limitations, the crop coefficient technique is still used worldwide because of its simplicity (Allen, 2000; Allen and others, 2005a).

Remote sensing data have been useful in developing methods for estimating consumptive water use from $E T_{a}$ that are scalable and transferable, which is important because apportionment of water resources is affected by environmental and economic circumstances differing in extent and spatiotemporal resolution. Research over many years has led to the development of remote sensing methods that are reliably reproducible and effective in estimating $E T_{a}$. Since satellites first began collecting data on natural resources in the 1970s, researchers have been developing models to process these data for estimating $E T_{a}$ (Idso and others, 1975; Jackson and others, 1977). Some remote sensing methods for estimating $E T_{a}$ are focused at very local scales (Jackson and others, 1977), whereas others are focused at scales ranging from regional or continental (Senay and others, 2013; Singh and Senay, 2016) to global (Mu and others, 2007). These methods also range from simple (Jackson and others, 1977) to complex (Bastiaanssen and others, 1998a; Allen and others, 2007b).

Several remote sensing methods can be used to estimate $E T_{a}$ at the high spatial resolution of agricultural fields and the large extent of river basins - a scale that is useful to water resource managers.

\section{Purpose and Scope}

This report, prepared in cooperation with the International Joint Commission, provides an overview of selected remote sensing methods used for estimating water consumed through $E T_{a}$. Two of the more recently developed methods are discussed in detail, Mapping Evapotranspiration at High Resolution with Internalized Calibration (METRIC) and Operational Simplified Surface Energy Balance (SSEBop), including the theory behind the continued improvement of these methods and some of their applications in $E T_{a}$ estimation. Various qualities of these methods, including the extent and spatiotemporal resolution of model estimates and their accuracies, the cost, and the ease of implementation, also are discussed in comparing the usefulness of the two methods for a particular project. This report is not intended to provide a systematic review of all remote sensing methods that have been developed to estimate consumptive water use from $E T_{a}$, but rather a synopsis of some recently developed techniques that currently (2017) seem most applicable to $E T_{a}$ estimation at scales appropriate for water resource management, along with a discussion of the potential for cloud computing to enable the operability of these techniques over large extents at high spatiotemporal resolution.

\section{Review of Remote Sensing Methods for Estimating Actual Evapotranspiration}

The use of remote sensing data for estimating $E T_{a}$ began in the 1970s ( $\mathrm{Li}$ and others, 2009). Original remote sensing methods have been improved over the years with refinements in modeling the processes that affect $E T_{a}$ as well as advances in satellite technology and computing power. These developments have meant that fewer ground-based measurements of model parameters are required, and models can be applied more accurately over larger extents at higher spatiotemporal resolution.

\section{Initial Empirical Methods}

One of the earliest remote sensing methods for estimating $E T_{a}$ was a simplified empirical regression model that estimated $E T_{a}$ from the difference between surface and air temperatures (Jackson and others, 1977):

$$
E T_{a}=R_{n}-B\left(T_{s}-T_{a}\right)
$$

where

$R_{n} \quad$ is net radiation, in watts per square meter;

$B \quad$ is a composite constant related to undefined parameters;

$T_{s} \quad$ is land surface temperature, in kelvins; and

$T_{a} \quad$ is air temperature, in kelvins. 
Remote sensing data are used to generate $R_{n}$ and $T_{s}$, but $T_{a}$ is taken from on-the-ground measurements and $B$ requires site-specific parameterization using ordinary least squares fit to empirical data. Jackson and others (1977) determined that this model estimated $E T_{a}$ reasonably well for a wheat field in Arizona.

Other researchers have revised parameterization of the model of Jackson and others (1977) and have developed modifications (additional exponents and/or coefficients) that improve its scalability and transferability. Seguin and Itier (1983) determined that the model parameters were most strongly influenced by atmospheric stability, wind speed, and surface roughness, which allowed for a more standardized parameterization of the model. Nieuwenhuis and others (1985) tried to ease the constraints of site-specific parameterization using a boundary layer model to simulate the model parameters. Taconet and others (1986) also used a boundary layer model to simulate the model parameters relative to changes in surface roughness, wind speed, and vegetation. Because of these physical factors, $E T_{a}$ estimates from the Jackson and others (1977) model were determined to be very sensitive to the height above the surface that $T_{a}$ is measured (Carlson and Buffum, 1989). This finding made it reasonable to use remote sensing data for generating $T_{a}$ like other parameters in the model. It was shown that $T_{a}$ became less influenced by surface features when estimated at least 50 meters (m) above the surface, which reduces some of the need for on-the-ground measurements. Moreover, this finding made it possible to scale the model from local to regional extents, although $E T_{a}$ estimates were produced at a coarse resolution beyond the size of most agricultural plots (Seguin and others, 1994).

The model of Jackson and others (1977) for estimating $E T_{a}$ is expedient because of its simplicity-the only data requirements being $T_{s}, T_{a}$, and $R_{n}$-which has facilitated applications from local to regional scales. This model has been applied successfully in many areas under varied atmospheric conditions and vegetative cover (Nieuwenhuis and others, 1985; Carlson and Buffum, 1989; Seguin and others, 1994); in these three studies, the error in $E T_{a}$ estimation averaged about 1 millimeter $(\mathrm{mm})$ per day. All these applications, however, are limited by a need for site-specific parameterization that does not allow for transference to new locations. More complex analytical methods have been developed that overcome limitations of this earlier empirical method, and most use some form of the surface energy balance model.

\section{Current Surface Energy Balance Models}

More complex remote sensing methods for estimating $E T_{a}$ are grounded in the theory behind the surface energy balance model (Biggs and others, 2015), also known as the energy balance model, where available energy from shortwave and longwave radiation is balanced by fluxes from the heating of Earth's surface and phase changes of water such as $E T_{a}$. The
$E T_{a}$ is estimated by fully or partially solving the energy balance model (Khan and others, 2015):

$$
R_{n}=L E-H-G
$$

where

$R_{n} \quad$ is net radiation, in watts per square meter; $L E \quad$ is latent heat flux (energy consumed through $E T_{a}$ ), in watts per square meter;

$H$ is sensible heat flux (energy convected to the air), in watts per square meter; and

$G$ is ground heat flux (energy conducted to the ground), in watts per square meter.

Additionally, these methods apply an analytical approach to $E T_{a}$ estimation using physically based models of varied complexity that require a combination of ground-based and remote sensing data.

Surface energy balance models can be divided into two categories: single-source energy balance models, where vegetation and soil are analyzed in a combined energy budget, and dual-source energy balance models, where vegetation and soil energy budgets are analyzed separately. Single-source energy balance models include Surface Energy Balance Algorithm for Land (SEBAL; Bastiaanssen and others, 1998a), Simplified Surface Energy Balance Index (S-SEBI; Roerink and others, 2000), Surface Energy Balance System (SEBS; Su, 2002), Mapping Evapotranspiration at High Resolution with Internalized Calibration (METRIC; Allen and others, 2007b), and Operational Simplified Surface Energy Balance (SSEBop; Senay and others, 2007; 2013). Dual-source energy balance models include the Two-Source Model (TSM; Norman and others, 1995), Two-Source Time Integrated Model (TSTIM; Anderson and others, 1997), Atmosphere-Land Exchange Inverse (ALEXI; Mecikalski and others, 1999), Dual Temperature Difference (DTD; Norman and others, 2000), and Enhanced Two-Source Evapotranspiration Model for Land (ETEML; Yang and others, 2015).

The premise for using dual-source energy balance models to estimate $E T_{a}$ is that they better estimate evaporation from bare surfaces, whereas single-source energy balance models are best used for estimating transpiration from vegetated surfaces. However, dual-source energy balance models can require more data and parameterization and do not seem to provide greatly improved estimates of $E T_{a}$ compared to singlesource models (Timmermans and others, 2007; French and others, 2015). The theory and application of many of these methods have already been reviewed in detail (Gowda and others, 2008a; Li and others, 2009; Liou and Kar, 2014) and are beyond the scope of this report. Instead, this report focuses on METRIC and SSEBop, two energy balance models for estimating $E T_{a}$ that are currently applied successfully in the United States. 


\section{Mapping Evapotranspiration at High Resolution with Internalized Calibration (METRIC)}

Allen and others (2007a; 2007b) developed METRIC, which is one of the more successfully applied remote sensing methods for estimating $E T_{a}$ with the energy balance model (eq. 2). The METRIC model can produce maps of $E T_{a}$ at high spatial resolution (30 $\mathrm{m}$ using Landsat data) for specific areas smaller than several hundred square kilometers in extent (Allen and others, 2007a), an improvement in practice over methods used more generally at larger scales. This method has been applied for many purposes, including planning of water resources, modeling of watershed hydrology, mapping of water use by riparian vegetation, monitoring of water rights compliance, evaluation of aquifer depletion from pumpage, and assessment of irrigation performance (Allen and others, 2007a).

\section{Theory}

The METRIC model is a further development of the techniques used by SEBAL (Bastiaanssen and others, 1998a). Both models estimate $E T_{a}$ as a residual of the energy balance at the land surface using equation 2 (Allen and others, 2007b). To compute the parameters in equation 2, METRIC uses shortwave and longwave radiation from satellite imagery, a 30-m digital elevation model (DEM), and hourly ground-based weather data near the study area (Allen and others, 2007b). In brief, METRIC computes net radiation $\left(R_{n}\right)$ from narrowband reflectance and surface temperature; ground heat flux $(G)$ from $R_{n}$, surface temperature, and vegetation indices; and sensible heat flux $(H)$ from surface temperature, wind speed, and surface roughness.

Net radiation $\left(R_{n}\right)$ in equation 2 is computed by adding all incoming radiation and subtracting all outgoing radiation:

$$
R_{n}=R_{S \downarrow}-\alpha R_{S \downarrow}+R_{L \downarrow}-R_{L \uparrow}-\left(1-\varepsilon_{0}\right) R_{L \downarrow}
$$

where

$$
\begin{array}{cl}
R_{S \downarrow} & \text { is incoming shortwave radiation, in watts per } \\
\alpha & \text { square meter; } \\
R_{L \downarrow} & \text { is surface albedo (dimensionless); } \\
& \text { is incoming longwave radiation, in watts per } \\
R_{L \uparrow} & \text { square meter; } \\
& \text { is outgoing longwave radiation, in watts per } \\
\varepsilon_{0} & \text { square meter; and } \\
& \text { is broadband surface thermal emissivity } \\
\text { (dimensionless). }
\end{array}
$$

These intermediate parameters are calculated in METRIC with numerous submodels that apply additional parameters derived from the ground-based weather data, DEM, and satellite imagery (Allen and others, 2007b).

Ground heat flux $(G)$ in equation 2 is computed with one of two alternative submodels (Bastiaanssen, 2000; Tasumi, 2003). Both submodels apply empirical relationships between $R_{n}, \alpha$, surface temperature, and a vegetation index to compute $G$ (Allen and others, 2007b). Bastiaanssen (2000) uses normalized difference vegetation index (NDVI) as the vegetation index, whereas Tasumi (2003) uses leaf area index (LAI).

Sensible heat flux $(H)$ in equation 2 is computed with an aerodynamic function:

$$
H=\rho_{a i r} C_{p} \frac{d T}{r_{a h}}
$$

where

$$
\begin{array}{cc}
\rho_{\text {air }} & \text { is density of air, in kilograms per cubic meter; } \\
C_{p} & \text { is specific heat of air at constant pressure, in } \\
\text { joules per kilogram per kelvin; } \\
d T \quad \text { is temperature difference between two near } \\
\text { surface heights, } Z_{1} \text { and } Z_{2}, \text { in kelvins; and } \\
r_{a h} \quad \text { is aerodynamic resistance (surface roughness } \\
\text { and atmospheric stability) between } Z_{1} \text { and } \\
Z_{2}, \text { in seconds per meter. }
\end{array}
$$

Wind speed, elevation, and LAI or NDVI are used to calculate $r_{a h}$ with several submodels in an iterative process (Allen and others, 2007b). The temperature gradient $(d T)$ is calculated with a linear function developed by Bastiaanssen (1995):

$$
d T=a+b T_{\text {sdatum }}
$$

where

$$
\begin{aligned}
a & \text { is the intercept; } \\
b & \text { is the slope; and } \\
T_{\text {sdatum }} & \begin{array}{l}
\text { is land surface temperature adjusted to a } \\
\text { standard elevation per pixel of the satellite } \\
\text { image, in kelvins. }
\end{array}
\end{aligned}
$$

The parameter $T_{\text {sdatum }}$ corrects for temperature change within a satellite image that is related to elevational change but unrelated to $d T$ or $H$ (Allen and others, 2007b).

The METRIC model reduces the complications of other methods that use the surface energy balance model (eq. 2) by focusing its calibration on computing $H$ and internalizing the errors and biases associated with computing $L E$ (Allen and others, 2007b). This calibration primarily depends on $d T$, which is indexed to surface temperature estimated radiometrically rather than measured on the ground, simplifying the computation of $H$. Two reference pixels are used to define the evaporative extremes of the energy balance at the land surface. Both pixels are chosen by the user to represent the range of $d T$ over the land surface. A "cold" (also called "wet") reference pixel is selected in a well-irrigated field with full vegetative cover where $E T_{a}$ is assumed to equal reference evapotranspiration $\left(E T_{r}\right)$. The standardized Penman-Monteith equation (American Society of Civil Engineers, 2005) is used to calculate $E T_{r}$. The sensible heat flux for the cold pixel $\left(H_{\text {cold }}\right)$ is calculated with the energy balance model:

$$
H_{\text {cold }}=\left(R_{n}-G\right)_{\text {cold }}-L E_{\text {cold }}
$$


where

$$
\begin{gathered}
R_{n \text { cold }} \quad \begin{array}{c}
\text { is net radiation at the cold pixel, in watts per } \\
\text { square meter; }
\end{array} \\
G_{\text {cold }} \quad \begin{array}{c}
\text { is ground heat flux at the cold pixel, in watts } \\
\text { per square meter; and }
\end{array} \\
L E_{\text {cold }} \quad \begin{array}{c}
\text { is latent heat flux at the cold pixel, in watts } \\
\text { per square meter. }
\end{array}
\end{gathered}
$$

Research has shown that the coldest (wettest) agricultural fields have $E T_{a}$ rates about 5 percent greater than those for a reference alfalfa crop (Tasumi and others, 2005a), so for the cold pixel, the ratio of $L E$ to $E T_{r}$ is assumed to be 1.05 ; however, this assumption does not apply outside of, or at the beginning of, the growing season when the abundance of vegetation is much less than that of the reference alfalfa crop. During these times of the growing season, a more appropriate ratio of $L E$ to $E T_{r}$ for the cold pixel can be calculated with a function of NDVI defined by the user (Allen and others, 2007b). The temperature gradient for the cold pixel $\left(d T_{\text {cold }}\right)$ is calculated with the inverse of equation 4 :

$$
d T_{\text {cold }}=\frac{H_{\text {cold }} r_{\text {ah cold }}}{\rho_{\text {air cold }} C_{p}}
$$

where

$$
\begin{array}{cc}
H_{\text {cold }} & \begin{array}{c}
\text { is sensible heat flux at the cold pixel, in watts } \\
\text { per square meter; }
\end{array} \\
r_{\text {ah cold }} & \begin{array}{c}
\text { is surface roughness and atmospheric stability } \\
\text { at the cold pixel, in seconds per meter; }
\end{array} \\
\rho_{\text {air cold }} & \begin{array}{c}
\text { is density of air at the cold pixel, in kilograms } \\
\text { per cubic meter; and }
\end{array} \\
C_{p} & \begin{array}{c}
\text { is specific heat of air at constant pressure, in } \\
\text { joules per kilogram per kelvin. }
\end{array}
\end{array}
$$

The "hot" (also called "dry") reference pixel is chosen in a dry, bare field where $E T_{a}$ is assumed to be zero. Unlike SEBAL, METRIC verifies this assumption with a daily soil water balance model, which determines whether evaporation is greater than zero because of antecedent moisture (Allen and others, 2007b). The calculations of $H$ and $d T$ for the hot pixel are the same as those for the cold pixel (eqs. 6 and 7, respectively). The values for $d T$ and $T_{\text {sdatum }}$ for the hot and cold pixels are used to calculate the two coefficients $(a, b)$ in equation 5 :

$$
\begin{gathered}
a=\frac{d T_{\text {hot }}-d T_{\text {cold }}}{T_{\text {sdatum hot }}-T_{\text {s datum cold }}} \\
b=\frac{d T_{\text {hot }}-a}{T_{\text {sdatum hot }}}
\end{gathered}
$$

where

$$
\begin{aligned}
& d T_{\text {hot/cold }} \quad \text { is temperature gradient at the hot/cold pixel, } \\
& \text { in kelvins; and } \\
& T_{\text {sdatum hotcold }} \quad \text { is land surface temperature at the hot/cold } \\
& \text { pixel adjusted to a standard elevation per } \\
& \text { pixel of the satellite image, in kelvins. }
\end{aligned}
$$

Once the user determines the linear relationship between $d T$ and $T_{\text {sdatum }}$ (eq. 5), $H$ is computed for each pixel of the satellite image.

The values for $G$ and $H$ are subtracted from that of $R_{n}$ to compute $L E$, the energy consumed through $E T_{a}$. Subsequently, $L E$ is used to estimate $E T$ for each pixel of the satellite image:

$$
E T_{\text {inst }}=3600 \frac{L E}{\lambda \rho_{w}}
$$

where

$$
\begin{array}{cl}
E T_{\text {inst }} & \begin{array}{c}
\text { is instantaneous } E T_{a} \text { (depth of liquid } \\
\text { evaporated at the time of the satellite } \\
\text { image), in millimeters per hour; }
\end{array} \\
3600 & \begin{array}{c}
\text { is a factor for converting from seconds to } \\
\text { hours; }
\end{array} \\
L E & \begin{array}{l}
\text { is latent heat flux, in watts per square meter; } \\
\text { is latent heat of vaporization, in joules per } \\
\text { kilogram; and }
\end{array} \\
\rho_{w} & \text { is density of water (about 1,000 kilograms per } \\
& \text { cubic meter). }
\end{array}
$$

The $E T_{a}$ is extrapolated to a daily time scale by calculating $E T_{r}$ fraction $\left(E T_{r} F\right)$, which is equivalent to the crop coefficient for the cold pixel (Allen and others, 2007b):

$$
E T_{r} F=\frac{E T_{\text {inst }}}{E T_{r}}
$$

where

$$
\begin{gathered}
E T_{\text {inst }} \quad \text { is instantaneous } E T_{a} \text {, in millimeters per hour; } \\
E T_{r} \quad \text { is reference } E T \text { at the time of the satellite } \\
\quad \text { image, in millimeters per hour. }
\end{gathered}
$$

It is assumed that $E T_{r} F$ is constant throughout the day - an assumption that Allen and others (2007b) verified with observational data - and $E T_{r} F$ is used to calculate daily $E T_{a}\left(E T_{24}\right)$ :

$$
E T_{24}=E T_{r} F \times E T_{r 24}
$$

where

$$
\begin{array}{ll}
E T_{r} F & \text { is } E T_{r} \text { fraction (dimensionless); and } \\
E T_{r 24} & \text { is } E T_{r} \text { cumulated over } 24 \text { hours on the date of } \\
\text { the satellite image, in millimeters. }
\end{array}
$$

With the assumption that $E T_{a}$ for the study area varies in proportion to changes in $E T_{r}$ at the weather station, $E T_{a}$ is extrapolated to a monthly or seasonal period $\left(E T_{\text {period }}\right)$ by interpolating $E T_{r} F$ between successive dates of satellite images (using a linear or curvilinear function) and multiplying by $E T_{r}$ for each day:

$$
E T_{\text {period }}=\sum_{i=m}^{n}\left(E T_{r} F_{i} \times E T_{r 24 i}\right)
$$


where

$$
\begin{aligned}
& E T_{\text {period }} \quad \text { is } E T_{a} \text { cumulated over a period from days } m \text { to } \\
& n \text {, in millimeters; } \\
& E T_{r} F_{i} \quad \text { is } E T_{r} F \text { interpolated over day } i \\
& \text { (dimensionless); and } \\
& E T_{r 24 i} \text { is } E T_{r} \text { cumulated over } 24 \text { hours for day } i \text {, in } \\
& \text { millimeters. }
\end{aligned}
$$

One satellite image for each month can be sufficient to estimate seasonal $E T_{a}$ (Allen and others, 2007b), but during times of rapid vegetative growth, multiple dates of satellite images may be needed. In addition, one weather station can be adequate for calculating $E T_{r}$ (Allen and others, 2007b), but if the study area is very heterogeneous and multiple stations are available, the user may need to apply METRIC to separate sections in the study area.

Lastly, unlike SEBAL, METRIC uses $E T_{r} F$ to extrapolate $E T_{a}$ from instantaneous to daily instead of using the evaporative fraction $(E F)$, which is the ratio of $E T_{a}$ to available energy $\left(R_{n}-G\right)$. Research has shown that $E F$ underestimates daily $E T_{a}$ in drier climates (Allen and others, 2007b), whereas $E T_{r} F$ incorporates changing weather such as wind and humidity that affect advection of heat throughout the day because these changes are integrated in the calculation of $E T_{r}$, which is done hourly and summed over 24 hours.

\section{Application}

Several studies have compared on-the-ground measurements of $E T_{a}$ to satellite-based estimates from METRIC. Estimates of $E T_{a}$ from METRIC were compared to measurements from lysimeters near Montpelier, Idaho, for a 150- by 300-kilometer $(\mathrm{km})$ portion (two Landsat scenes) of the Bear River basin (Allen and others, 2007a). Measurements of $E T_{a}$ were taken with lysimeters located near an irrigated field of a native sedge forage crop that was characteristic of the area. Estimates of $E T_{a}$ were made with METRIC for a field close to the lysimeters on four dates throughout the 1985 growing season. The least accurate monthly $E T_{a}$ estimate was for July 14, which had a difference of 28 percent between the estimated and measured $E T_{a}$; however, this difference was deemed reasonable because of vegetation growing rapidly at that time and precipitation preceding the date of the satellite image. The average difference between monthly $E T_{a}$ estimated with METRIC and that measured with the lysimeters was plus or minus 16 percent. When data for the growing season were compared, the difference was only 4 percent, which was attributed to the reduction in random errors associated with each monthly METRIC estimate and lysimeter measurement (Allen and others, 2007a).

Estimates of $E T_{a}$ from METRIC also were compared to lysimeter measurements on the Snake River Plain near Kimberly, Idaho, on eight dates of Landsat 5 scenes during the 1989 growing season (Allen and others, 2007a). The lysimeters had been measuring $E T_{a}$ for more than 20 years over a range of ground cover and weather conditions, enabling comparisons of those measurements to estimates of $E T_{a}$ from
METRIC over various times of the growing season and for various crop types and growth stages. This study showed that METRIC functioned consistently across clear, partly cloudy, and cloudy days, validating the assumption that $E T_{r} F$ for a daily time scale can be estimated by instantaneous $E T_{r} F$ at the time of the satellite image. Estimates of $E T_{r} F$ for the 24-hour period were within 5 percent of instantaneous $E T_{r} F$ in nearly all samples for clipped grass and sugar beets. Estimates of $E T_{a}$ from METRIC were least accurate during the early and late growing season, which had differences of 139 percent for April 18 and 34 percent for September 25, although the difference for April 18 was partially attributed to drying of recently wetted bare ground. When omitting the value for April 18, the average difference was 14 percent. Like the study from Montpelier, Idaho, this difference decreased when data for the growing season were compared. Measured by the lysimeters, the seasonal $E T_{a}$ of the sugar beet crop was $718 \mathrm{~mm}$, whereas the estimate from METRIC was $714 \mathrm{~mm}$, a difference of less than 1 percent (Allen and others, 2007a).

Estimates of $E T_{a}$ from METRIC also have been compared to those made with SEBAL. The two models were applied independently in southern Idaho to two partially overlapping Landsat 5 and 7 scenes in 2000 (Tasumi and others, 2005b). These independent applications of METRIC and SEBAL involved different users, different pathways and dates for the Landsat scenes, different weather stations, and different choices of the hot and cold reference pixels. Monthly and seasonal estimates of $E T_{a}$ made with SEBAL and METRIC were compared for pixels sampled from the overlapping portion of the Landsat scenes. The seasonal estimates of $E T_{r} F$ from METRIC and $E F$ from SEBAL were consistent and repeatable; coefficients of determination $\left(r^{2}\right.$; Helsel and Hirsch, 2002) were 0.59 and 0.58 and standard deviations were 0.06 percent and 0.05 percent, respectively, in comparisons of the two scenes. The monthly estimates had more variability because data were less available in some months. These applications demonstrated the value of METRIC for estimating $E T_{a}$ of agriculture in the semi-arid western United States.

Another application of METRIC has been to improve estimates of water balance models that have used empirical models, rather than a physically based surface energy balance model, to estimate $E T_{a}$. Using METRIC to estimate $E T_{a}$, Santos and others (2008) applied a water balance model to produce more efficient irrigation schedules for the Genil-Cabra Irrigation Scheme of Spain. The high temporal resolution of the water balance model and the high spatial resolution of the satellite imagery provided near real-time estimates of $E T_{a}$ from METRIC to improve irrigation scheduling for individual agricultural plots. The study area consisted of 6,800 hectares (ha) of irrigated farmland with a diversity of crop types, including wheat, cotton, olive, maize, sugar beet, beans, garlic, sunflower, and other vegetables. Landsat scenes on 11 dates in 2004-5 and weather data from five ground-based stations were used to make estimates with the model. Among plots, estimates of $E T_{a}$ from METRIC ranged from $0 \mathrm{~mm}$ for non-agricultural fields in the study area to $1,000 \mathrm{~mm}$ for some 
well-irrigated plots of sugar beet. The estimates showed high variability in crop coefficients ( $E T_{a}$ from METRIC divided by $E T_{r}$ ) among the crop types, suggesting in part suboptimal irrigation scheduling. In addition, the estimates showed great variability within plots, ranging from $70 \mathrm{~mm}$ for pepper (12 percent of seasonal $E T_{a}$ ) to $160 \mathrm{~mm}$ for sunflower (44 percent of seasonal $E T$ ). Using the model estimates to update the irrigation schedule in real-time would have reduced the watering depth from $733 \mathrm{~mm}$ to $559 \mathrm{~mm}$ for cotton, a 24-percent decrease in water use, but would have increased water use for sugar beet by 21 percent. Estimated $E T_{a}$ from METRIC for selected crops and plots was $677 \mathrm{~mm}$, whereas the measured delivery of irrigation water was $699 \mathrm{~mm}$, an error of 3 percent. In this application, METRIC provided estimates of $E T_{a}$ at high spatiotemporal resolution, improving irrigation performance and water consumption throughout the growing season for individual agricultural plots.

Gowda and others (2008b) applied METRIC to $E T_{a}$ estimation in the Texas High Plains near Lake Meredith in agricultural fields dependent on irrigation water pumped from the Ogallala Aquifer. The study area encompassed 234,000 ha, about one-half of which were planted with corn, cotton, sorghum, soybean, and wheat, and the rest had interspersed semi-arid shrubs and grasses. The study area experiences strong winds and temperature gradients across the landscape during the growing season, affecting advection of heat, which is responsible for more than half of $E T_{a}$. Estimates of $E T_{a}$ were made with METRIC using Landsat 5 scenes on two dates (June 27 and July 29) in 2005 and ground-based weather data from four stations. Estimates of $E T_{a}$ in four fully or partially irrigated fields of corn and cotton, experiencing varied water stress, were compared to a daily soil water balance model. The partially irrigated cotton field had relatively high differences between estimated and measured $E T_{a}$, potentially because of less plant biomass and more bare soil. When omitting the values for this field, the average difference was 13 percent and -5 percent on June 27 and July 29, respectively, which Gowda and others (2008b) deemed exceptional given the prevailing weather conditions that promote advection of heat.

Most applications of METRIC have been at local scales at high spatial $(30 \mathrm{~m})$ but lower temporal (8-16 days) resolution using data from Landsat 5, 7, and 8. Few studies have attempted to apply METRIC or SEBAL at regional scales at lower spatial (250-1,000 m) but higher temporal (1-2 days) resolution using data from Moderate Resolution Imaging Spectroradiometer (MODIS). Data from MODIS were used in applications of SEBAL in Brazil and China (Ruhoff and others, 2012; Yang and others, 2012). Trezza and others (2013) used METRIC with MODIS data in a study of a 3- by 3-degree section of the Middle Rio Grande Basin in New Mexico. The main difficulty in using METRIC with low spatial resolution $(1 \mathrm{~km})$ MODIS data is the selection of hot and cold reference pixels that are uniform within 1 square kilometer $\left(\mathrm{km}^{2}\right)$, the area of a pixel. To overcome this limitation, the cold pixel was chosen with a procedure that incorporated MODIS and Landsat 5 data, whereas the hot pixel selection was made with MODIS data. Comparisons were made between METRIC estimates of $E T_{a}$ using MODIS and Landsat 5 data for scenes on 13 dates in 2002 . Estimates of $E T_{a}$ using data from MODIS were lower than those made with Landsat for pixels with high NDVI but comparable for pixels with low NDVI. Moreover, $E T_{a}$ estimates made with MODIS data were highly correlated with those using Landsat $\left(r^{2}=0.9\right)$; annual $E T_{a}$ averaged over the Middle Rio Grande Basin was $1,045 \mathrm{~mm}$ with MODIS and 1,067 $\mathrm{mm}$ with Landsat. Uncertainty of $E T_{a}$ estimates for individual agricultural plots, however, was very high when using METRIC with MODIS data.

\section{Operational Simplified Surface Energy Balance (SSEBop)}

Senay and others (2013) developed SSEBop, which is the most recent revision of Simplified Surface Energy Balance (SSEB; Senay and others, 2007). Because SSEBop builds on the theory from SSEB, this section will focus first on SSEB and then discuss its progression toward SSEBop. Similar to METRIC, SSEBop is another remote sensing method that applies the simplified version of the surface energy balance model (eq. 2) to estimate $E T_{a}$. Applications of this method also have had many purposes, including drought monitoring and famine early warning in regions with sparse ground-based data, mapping of water use by different land cover classes, and estimation of $E T_{a}$ in the United States at regional to continental scales (Senay and others, 2007; 2011a; 2013; 2016). The SSEBop model has been used to produce maps of $E T_{a}$ over very large extents (the conterminous United States) using lower spatial resolution $(1 \mathrm{~km})$ MODIS data (Senay and others, 2016). Unlike METRIC, SSEBop requires less parameterization of the energy balance model, making for simpler application over larger extents, and does not have the same requirements for finely resolved ground-based data such as hourly weather information.

\section{Theory}

The SSEB model functions similarly to METRIC (Allen and others, 2007b). The METRIC model assumes that variation in land surface temperature (LST) is linearly related to the temperature difference between the land surface and air. This relation is defined through the selection of two reference pixels: a hot pixel that represents bare, dry fields; and a cold pixel that represents vegetated, wet fields. The temperature gradient is used in equation 2 to estimate $H$ (sensible heat flux), which is assumed to vary linearly between the hot and cold pixels. This assumption holds for SSEB, where it is further assumed that $L E$ in equation 2 (energy consumed through $E T_{a}$ ) also varies linearly between the hot and cold pixels. Senay and others (2007) remark that this assumption is supported by research showing that the temperature difference between the land surface and air is linearly related to soil moisture. They additionally assume that $E T_{a}$ can be inferred from the temperature gradient, which can be estimated from land surface 
temperatures of the hot and cold pixels. At the hot pixel, $E T_{a}$ is assumed to be zero, and $E T_{a}$ at the cold pixel is assumed to be maximal - that is, to equal $E T_{r}$. At all other pixels in a study area, $E T_{a}$ is scaled proportionately to the surface temperature of each pixel in relation to that of the hot and cold pixels. With this assumption, fractional evapotranspiration $\left(E T_{f}\right)$ is calculated for each pixel:

$$
E T_{f}=\frac{T_{h}-T_{s}}{T_{h}-T_{c}}
$$

where

$T_{h} \quad$ is LST for the hot pixel, in kelvins;

$T_{s} \quad$ is LST of each pixel, in kelvins; and

$T_{c} \quad$ is LST for the cold pixel, in kelvins.

To calculate the parameters in equation 14, SSEB uses satellite imagery for LST and a vegetation index (NDVI) to assist in choosing the hot and cold reference pixels. From the study area, regions of high temperature and low NDVI (hot, bare fields) and low temperature and high NDVI (cold, wellvegetated fields) are identified from which the hot and cold reference pixels are chosen. The $E T_{a}$ is calculated from $E T_{f}$ for each pixel in the study area:

$$
E T_{a}=E T_{f} \times E T_{0}
$$

where

$$
\begin{aligned}
& E T_{f} \quad \text { is fractional ET (dimensionless); and } \\
& E T_{0} \quad \text { is reference ET, in millimeters. }
\end{aligned}
$$

Available gridded data such as those from the Global Data Assimilation System (GDAS) model are used to calculate $E T_{0}$, which results in a 1-degree grid of global daily data (Senay and others, 2008). The GDAS model uses the standardized Penman-Monteith equation (American Society of Civil Engineers, 2005) to compute $E T_{0}$ for a shortgrass crop (Allen and others, 1998). Senay and others (2007) disaggregate the 1-degree data from this model onto a 10-km grid. However, if $E T_{0}$ is available from a weather station, $E T_{a}$ estimates will likely be more accurate using the local values of $E T_{0}$.

A major assumption of SSEB is that differences in LST over a homogeneous landscape are related to differences in vegetation and its water use (Senay and others, 2007). Because this assumption ignores $\alpha$ and $G, E T_{a}$ is underestimated for surfaces with low albedo (light reflectance) and overestimated for surfaces with high albedo and high ground heat flux, such as bare soils (Senay and others, 2011a). In addition, SSEB assumes that LST and $E T_{a}$ are linearly related, but this assumption is questionable if $\alpha$ and $G$ of a pixel on the landscape differ greatly from that of the reference crop (Senay and others, 2011a). To better support these assumptions, Senay and others (2011a) developed an adaptation of SSEB (SSEBelvi) with a correction for elevation with a DEM and another correction for land cover with a vegetation index. These modifications were developed to improve SSEB in applications on landscapes with varied elevation, slope, or aspect, and with mixed bare soil and green or senesced vegetation.

To improve SSEB for applications not just on flat, irrigated fields but also on more complicated terrain, LST is corrected for topographic differences:

$$
L S T_{c}=L S T+K_{L} \times D E M
$$

where

$$
\begin{array}{cl}
L S T_{c} & \text { is } L S T \text { corrected for elevation, in kelvins; } \\
L S T & \text { is uncorrected } L S T, \text { in kelvins; } \\
K_{L} & \text { is lapse rate in temperature of air moving over } \\
\text { the landscape, in kelvins per meter; and } \\
D E M & \begin{array}{c}
\text { is land surface elevation from a digital } \\
\text { elevation model, in meters. }
\end{array}
\end{array}
$$

The standard value for the lapse rate is 0.0065 kelvins per meter. When using SSEBelvi, $L S T_{c}$ is substituted for $L S T$ to calculate $E T_{f}$ in equation 14 .

To improve the application of SSEB for mixed land cover, NDVI is used to correct for vegetation differences:

$$
E T_{f(e l v i)}=\left(0.35 \times \frac{N D V I}{0.7}+0.65\right) \times E T_{f(e l)}
$$

where

$$
\begin{aligned}
& E T_{\text {felvi) }} \quad \text { is } E T_{f} \text { corrected for elevation and vegetation } \\
& \text { index (dimensionless); } \\
& \text { NDVI is normalized difference vegetation index } \\
& \text { (dimensionless); and } \\
& E T_{f(e l)} \quad \text { is } E T_{f} \text { from equation } 14 \text { corrected for land }
\end{aligned}
$$

With SSEBelvi, it is assumed that if the NDVI value of a pixel is greater than 0.7 , that pixel is well-vegetated and will have $E T_{a}$ greater than that of the reference crop if water is not limiting (Senay and others, 2011a). The possible range of the coefficient in equation 17 (the resulting value of all terms within the parentheses) is $0.65-1.15$, but the probable maximum is 1.05 because NDVI is rarely greater than 0.8 for a pixel. Senay and others (2011a) state that this range has no strong theoretical basis, but that the probable maximum is equivalent to the correction factor used by METRIC (1.05) for calculating $E T_{f}$ of the cold reference pixel. When using SSEBelvi, $E T_{f(e l v i)}$ is substituted for $E T_{f}$ to calculate $E T_{a}$ in equation 15.

To reduce the potential for bias from the user selecting the hot and cold reference pixels in SSEB and SSEBelvi, SSEBop was developed with a procedure similar to that of SEBS (Su, 2002) to predetermine the difference between the hot and cold boundary conditions for each pixel (Senay and others, 2013). The SSEBop model, unlike METRIC, SSEB, and SSEBelvi, does not require the user to select the hot and cold reference pixels for a study area. The only data required are $T_{s}$, $T_{a}$, and $E T_{0}$. Senay and others (2013) state that their model is boldly simple, but that it is grounded in knowledge that available $R_{n}$ drives the surface energy balance model. They argue that under clear skies the hot and cold boundary conditions do 
not vary significantly among years, and more importantly the difference between the hot and cold reference values can be assumed constant for a given location and day of year. With this assumption, $E T_{a}$ is calculated as a fraction of $E T_{0}$ :

$$
E T_{a}=E T_{f} \times k E T_{0}
$$

where

$$
\begin{aligned}
& E T_{f} \quad \text { is fractional ET (dimensionless); } \\
& k \text { is a coefficient that scales } E T_{0} \text { to maximum } \\
& E T_{a} \text { of a less aerodynamic crop; and } \\
& E T_{0} \quad \text { is reference ET for a shortgrass crop, in } \\
& \text { millimeters. }
\end{aligned}
$$

The standard value for the coefficient is 1.2 , but it also can be determined with calibration procedures using soil water balance or surface energy balance approaches, or field data (Senay and others, 2013). The idealized hot and cold reference values for each pixel are used to calculate $E T_{f}$ in equation 14.

It is assumed that under clear-sky conditions $E T_{a}$ will be equivalent to potential ET if $T_{s}$ is similar to $T_{a}$ ( $H$ is minimal), so daily maximum air temperature $\left(T_{a}\right)$ can be multiplied by a correction factor to calculate land surface temperature for the cold pixel $\left(T_{c}\right)$ in equation 14 :

$$
T_{c}=c T_{a}
$$

where

$c \quad$ is a coefficient that relates $T_{s}$ to $T_{a}$ for wellirrigated vegetation at maximum $E T_{a}$; and

$T_{a} \quad$ is air temperature, in kelvins.

This assumption can be verified by relating $T_{s}$ to $T_{a}$ from remote sensing data for well-irrigated vegetation in the study area.

Land surface temperature for the hot pixel $\left(T_{h}\right)$ is calculated by adding the temperature difference to $T_{c}$ from equation 19:

$$
T_{h}=T_{c}+d T
$$

where

$$
\begin{gathered}
T_{c} \quad \begin{array}{l}
\text { is land surface temperature for the cold pixel, } \\
\text { in kelvins; and }
\end{array} \\
d T \quad \begin{array}{l}
\text { is temperature gradient between the idealized } \\
\text { hot and cold reference values for each } \\
\text { pixel, in kelvins. }
\end{array}
\end{gathered}
$$

The parameter $d T$ is predetermined for each pixel and day of year by partially solving the energy balance model for dry, bare soil where it is assumed that $E T_{a}$ is zero and $H$ is maximal (Bastiaanssen and others, 1998a; Allen and others, 2007b). Because $L E$ and $G$ in equation 2 are assumed to be zero at a daily time scale for bare, dry soil, $R_{n}$ can be estimated as $H$ in equation 4 , and $d T$ can be calculated with the inverse of equation 4. Senay and others (2013) used a trial-and-error calibration approach to determine $r_{a h}$, which they fix at 110 seconds per meter, a value also found in the range reported by other research (Qiu and others, 1998).

Lastly, satellite imagery can underestimate $T_{s}$ on some non-vegetated surfaces with high albedo, such as desert sands, or high emissivity, such as lava rocks. Consequently, SSEBop may overestimate $E T_{a}$ for these surfaces. To correct for this misinterpretation of $T_{s}$ when using SSEBop to estimate $E T_{a}$, either a mask is applied over these surfaces or a correction factor is used with $\alpha$ to increase $T_{s}$.

\section{Application}

The SSEB, SSEBelvi, and SSEBop models have been applied at local, regional, and continental scales, and tested against more complex remote sensing methods for estimating $E T_{a}$. Senay and others (2007) used SSEB to estimate $E T_{a}$ in irrigated agricultural lands in two river basins in Afghanistan during 2000-5. Because these river basins had varied temperature gradients, they were each divided by elevation into three subdivisions, ranging in size from 430 to $2,100 \mathrm{~km}^{2}$. Irrigated fields were delineated with data from Landsat, MODIS, and Advanced Spaceborne Thermal Emission and Reflection Radiometer (ASTER). Afghanistan lacked field data for model validation, but spatial and temporal patterns of estimated $E T_{a}$ were consistent with observations of vegetative cover from NDVI, estimates of $E T_{a}$ from a water balance model, and published reports of precipitation (Senay and others, 2007). Furthermore, in a preliminary validation of SSEB against METRIC applied to corn and soybean fields in South Dakota in 2001 with Landsat data (Senay and others, 2007), $E T_{a}$ estimates from both models were highly correlated $\left(r^{2}\right.$ greater than 0.9).

Satellite-based estimates of $E T_{a}$ from SSEB have been compared to on-the-ground measurements in several studies. Estimates of $E T_{a}$ using SSEB were compared to measurements taken with lysimeters near Bushland, Texas, on the Southern High Plains (Gowda and others, 2009). Lysimeters measured $E T_{a}$ in dryland and irrigated agricultural plots planted with corn and sorghum. Estimates of $E T_{a}$ were made with SSEB for Landsat scenes on 14 dates during the 2007 and 2008 growing seasons. Estimates of $E T_{a}$ from SSEB explained 84 percent of the variance in the daily measurements from lysimeters, and had a root mean square error (RMSE; Helsel and Hirsch, 2002) of $1.2 \mathrm{~mm}$. The differences between SSEB and the lysimeters mostly involved the dryland agricultural plots; SSEB overestimated $E T_{a}$ at lower values (less than $2.5 \mathrm{~mm}$ ) of lysimeter-measured daily $E T_{a}$ and underestimated $E T_{a}$ at higher values. It was determined that SSEB performed comparably to more complex energy balance models at estimating $E T_{a}$ in semi-arid landscapes. Gowda and others (2009) concluded that SSEB is promising for regional-scale applications because of its simplified approach with minimal data requirements.

Estimates of $E T_{a}$ made with SSEB also have been compared to those from a water balance model (Senay and others, 2011b). For 1,399 eight-digit hydrologic unit code (HUC8) subbasins in the conterminous United States, $E T_{a}$ 
was estimated using SSEB and was modeled as the difference between precipitation and runoff (Senay and others, 2011b). The comparison was made with the median values for precipitation and runoff for 2000-9. Estimates of $E T_{a}$ from SSEB and the water balance model were highly correlated $\left(r^{2}\right.$ greater than 0.9$)$ and had a mean error of $-67 \mathrm{~mm}$ (11 percent of the difference between precipitation and runoff). Senay and others (2011b) ascertained that SSEB showed the expected patterns of $E T_{a}$ across the contiguous United States but underestimated $E T_{a}$ in more arid regions. This underestimation most likely was due to the low spatial resolution $(1 \mathrm{~km})$ of MODIS data, which assimilates land within a $1-\mathrm{km}^{2}$ pixel that may not be contributing to $E T_{a}$.

Senay and others (2011a) compared spatial and temporal variation in $E T_{a}$ estimates from SSEBelvi to those from METRIC for agricultural fields in southern Idaho. Spatial variation in $E T_{a}$ estimates was compared for the whole study area on June 28,2003 , and temporal variation in $E T_{a}$ estimates was compared for six plots in Landsat scenes on seven dates throughout the 2003 growing season. For pixels in the study area at elevations less than 2,000 m, where the terrain was homogeneous, spatial variation in $E T_{a}$ estimates from SSEBelvi and METRIC were highly correlated, having a correlation coefficient ( $r$; Helsel and Hirsch, 2002) of 0.95. For pixels greater than $2,000 \mathrm{~m}$ in elevation, which had more complicated terrain, SSEBelvi tended to overestimate $E T_{a}$ at lower values of $E T_{a}$ estimated with METRIC; however, the corrections for elevation and vegetative cover with a DEM and NDVI were determined to improve the correlation between SSEB and METRIC for pixels at higher elevations $(r=0.62)$. Temporal variation in $E T_{a}$ estimates also was comparable between SSEBelvi and METRIC for most of the agricultural plots. Although SSEBelvi tended to overestimate $E T_{a}$ earlier in the growing season, it was similar to METRIC later in the growing season when daily or monthly $E T_{a}$ is much greater. Senay and others (2011a) surmised that selecting the cold reference pixel in a water body would help reduce this error.

Two studies have compared SSEBop estimates of $E T_{a}$ to eddy covariance measurements (Senay and others, 2013; Chen and others, 2016). In both studies, $E T_{a}$ estimates were compared to measurements taken at more than 40 flux towers covering diverse ecosystems across the contiguous United States, including cropland, grassland, forest, shrubland, and woody savanna. Senay and others (2013) parameterized SSEBop with monthly air temperature data in 2005 from Parameter-Elevation Regressions on Independent Slopes Model (PRISM) and found high correlation between monthly $E T_{a}$ estimates from SSEBop and eddy covariance measurements $\left(r^{2}=0.64 ;\right.$ RMSE $\left.=27 \mathrm{~mm}\right)$. Senay and others (2013) concluded that SSEBop is promising for applications at a continental scale given the minimal data requirements and the consistency of model estimates produced by different users. Chen and others (2016) parameterized SSEBop for monthly data during 2001-7 and determined that across five land cover classes, SSEBop estimates of $E T_{a}$ explained 86 percent of the variance in the monthly eddy covariance measurements and had an RMSE of $15 \mathrm{~mm}$. The model performed best for cropland $\left(r^{2}=0.92 ; \mathrm{RMSE}=13 \mathrm{~mm}\right)$. A sensitivity analysis of the model determined that errors in all six parameters might cause errors in $E T_{a}$ estimation as great as 30 percent, and that the model is most sensitive during the non-growing season and in more arid regions. Despite the potential for error in parameterizing SSEBop, Chen and others (2016) determined that uncertainty in the simplification of the model did not significantly affect how well SSEBop estimates $E T_{a}$ at a regional scale.

Singh and Senay (2016) compared $E T_{a}$ estimates from SSEBop to those from three different energy balance models (METRIC, SEBAL, and SEBS) for irrigated and non-irrigated farmlands in the midwestern United States. Estimates of $E T_{a}$ were made with Landsat scenes on seven dates throughout the 2001 growing season over three sites planted with maize and soybean. Estimates of $E T_{a}$ from METRIC, SEBAL, SEBS, and SSEBop were compared to eddy covariance measurements taken at the three sites. Singh and Senay (2016) determined that all four models demonstrated similar spatial and temporal patterns of $E T_{a}$. Performance of the models was evaluated with four metrics: $r, r^{2}$, Nash-Sutcliffe efficiency (NSE), and RMSE. The NSE compares the relative fit of model simulations to observed data and ranges from negative infinity to 1 , with 1 being the optimal value and values less than 0 being worse than the mean observed value (Nash and Sutcliffe, 1970). When compared to eddy covariance measurements, estimates of $E T_{a}$ made with METRIC had an $r, r^{2}$, NSE, and RMSE of $0.96,0.92,0.87$, and $93 \mathrm{~mm}$, respectively; for SSEBop, they were $0.96,0.92,0.90$, and $84 \mathrm{~mm}$, respectively.

Two studies have used $E T_{a}$ estimated with SSEBop to help improve water resource management in the Colorado River Basin (Singh and others, 2014a; Senay and others, 2016). In both studies, $E T_{a}$ was estimated with Landsat and MODIS data for 144 HUC8 subbasins. Singh and others (2014a) determined there was high correlation between SSEBop estimates of annual $E T_{a}$ made with high spatial resolution $(30 \mathrm{~m})$ Landsat data and eddy covariance measurements taken at seven sites in $2000\left(r^{2}=0.78\right)$; removing two sites affected by wildfire further increased the correlation $\left(r^{2}=0.95\right)$. Moreover, annual $E T_{a}$ estimates from SSEBop for the HUC8 subbasins were highly correlated with those from a water balance model $\left(r^{2}=0.85\right)$. Singh and others $(2014 b)$ also determined that estimates of annual $E T_{a}$ made with SSEBop using lower spatial resolution $(1 \mathrm{~km})$ MODIS data had high correlation to those made with Landsat data $\left(r^{2}=0.79\right)$. However, $E T_{a}$ estimates made with MODIS data were not spatially explicit enough to manage water resources at the field scale. Senay and others (2016) determined that SSEBop estimates of daily $E T_{a}$ were highly correlated to eddy covariance measurements taken at two sites ( $r^{2}$ greater than or equal to 0.82; RMSE less than or equal to $0.6 \mathrm{~mm}$ ), and annual $E T_{a}$ estimated with SSEBop had high correlation to that from a water balance model $\left(r^{2}=0.78 ;\right.$ RMSE $\left.=77 \mathrm{~mm}\right)$. To increase the temporal resolution of $E T_{a}$ estimates, SSEBop was parameterized with daily air temperature data from Daymet (Thornton and others, 1997). Senay and others (2016) analyzed $E T_{a}$ by 16 land 
cover classes and determined that shrubland, the dominant land cover, consumed 146 cubic kilometers $\left(\mathrm{km}^{3}\right)$ of water, whereas cropland consumed $4 \mathrm{~km}^{3}$. However, they determined that precipitation only provided 26-43 percent of water used by cropland in five irrigation districts, emphasizing the value of the high spatiotemporal resolution estimates to managing water resources.

\section{Comparison of METRIC and SSEBop Models}

The METRIC and SSEBop models each have been shown to estimate $E T_{a}$ with acceptable accuracies in many applications. A robust remote sensing method for estimating $E T_{a}$, METRIC has been applied successfully in the United States and internationally, and METRIC and SEBAL (the model from which METRIC was developed) have been used to estimate $E T_{a}$ in more than 25 countries and on all continents except Antarctica (Bastiaanssen and others, 1998b; 2005; Allen and others, 2007a). The SSEBop model largely has been used to estimate $E T_{a}$ in the United States (Senay and others, 2007; 2011a; 2013; 2016). The METRIC and SSEBop models have many similarities (table 1), including their theoretical grounding in the surface energy balance model and their ability to incorporate low $(1 \mathrm{~km})$ and high $(30 \mathrm{~m})$ spatial resolution data from MODIS and Landsat; however, they have important differences in data requirements, ease of implementation, and cost.

The METRIC model has shown greater accuracy at estimating $E T_{a}$ than simpler techniques that use crop coefficients or vegetation indices exclusively (Choudhury and others, 1994; Allen and others, 1998), and also removes the need to know crop type and growth stage (Allen and others, 2011a). The model can detect reductions in $E T_{a}$ from water shortages, soil salinity, and frozen soil, and can detect evaporative losses from bare soil. In addition, many studies validating METRIC estimates of $E T_{a}$ against measurements from lysimeters have shown model accuracies on daily to seasonal time scales ranging from 85 to 95 percent (Allen and others, 2007a).

The METRIC model is accurate and accounts for all terms of the energy balance model (table 1). The greater complexity of METRIC results in greater data requirements, including remote sensing data in the visible, near-infrared, and infrared regions of the electromagnetic spectrum, as well as on-the-ground measurements of wind speed and air temperature. Some of the complexity of solving the energy balance model is mitigated by the internalized calibration of METRIC, which reduces data requirements compared to more complex energy balance models; however, this internalized calibration leads to greater skill required for implementation compared to SSEBop.

Skill is required in the selection of the hot and cold reference pixels by the user, which is the principal determinant of the accuracy of METRIC. Long and Singh (2013) demonstrated that context dependency can affect this selection by the user. An appropriate reference pixel may not exist within a satellite image if all the land cover is vegetated (or non-vegetated), or the choice of the reference pixels can be affected if the extent or resolution of the satellite image changes, which in turn would change estimates of $E T_{a}$. User error in choosing the hot and cold reference pixels is the greatest source of error in $E T_{a}$ estimates from METRIC. To apply METRIC appropriately, the user needs background in the theoretical basis of the surface energy balance model and knowledge of the biophysics of vegetation. This user training and the sophistication of the physically based model means that METRIC can cost more than \$75,000 per year (in 2004 dollars) to estimate $E T_{a}$ for a Landsat scene (Allen and others, 2005b). Although METRIC may cost less than estimating $E T_{a}$ for a study area using crop coefficient techniques with on-theground measurements of reference ET, it is still expensive for a 1-year application.

Because of the training needed to apply METRIC properly and the variability in $E T_{a}$ estimates among even trained users, effort has been made to automate the calibration of METRIC (Allen and others, 2013). Morton and others (2013) developed an algorithm that might simplify $E T_{a}$ estimation with METRIC. Six trained users manually calibrated METRIC for estimating $E T_{a}$ with Landsat scenes from 2006 for a study area in Nevada. Statistics from empirical cumulative distribution functions of the selection of the hot and cold reference pixels by these users were used to parameterize the automated calibration algorithm. Comparisons of daily $E T_{a}$ estimates from the automated calibration to Bowen ratio and eddy covariance measurements at eight sites showed high correlation $\left(r^{2}=0.8\right)$. Morton and others (2013) affirmed that the automated calibration algorithm compared well to manual selection of the reference pixels, but that more validation is needed in other study areas with different crop types and growing conditions. The automated algorithm for selecting reference pixels is a promising development toward greater objectivity in METRIC estimates of $E T_{a}$, and more importantly a more user-friendly means of implementation.

In contrast, SSEBop is a simpler model (table 1), having reduced data requirements and greater ease of implementation without a substantial loss of accuracy in estimating $E T_{a}$. Performance has improved greatly from SSEB to SSEBelvi and SSEBop. Like other energy balance models, SSEBop does not perform as well on more complicated terrain, but Senay and others (2013) have suggested further adaptations of the model that may include corrections for slope and aspect in calculating net radiation. Additionally, model accuracies ranging from 80 to 95 percent on daily to annual time scales have been shown in numerous studies that validated $E T_{a}$ estimates from SSEBop against eddy covariance measurements (Senay and others, 2013; Chen and others, 2016).

The data requirements of SSEBop are air temperature, albedo, land surface elevation, NDVI, net radiation, reference ET, and land surface temperature, most of which are taken from remote sensing data (table 1). Although greater 


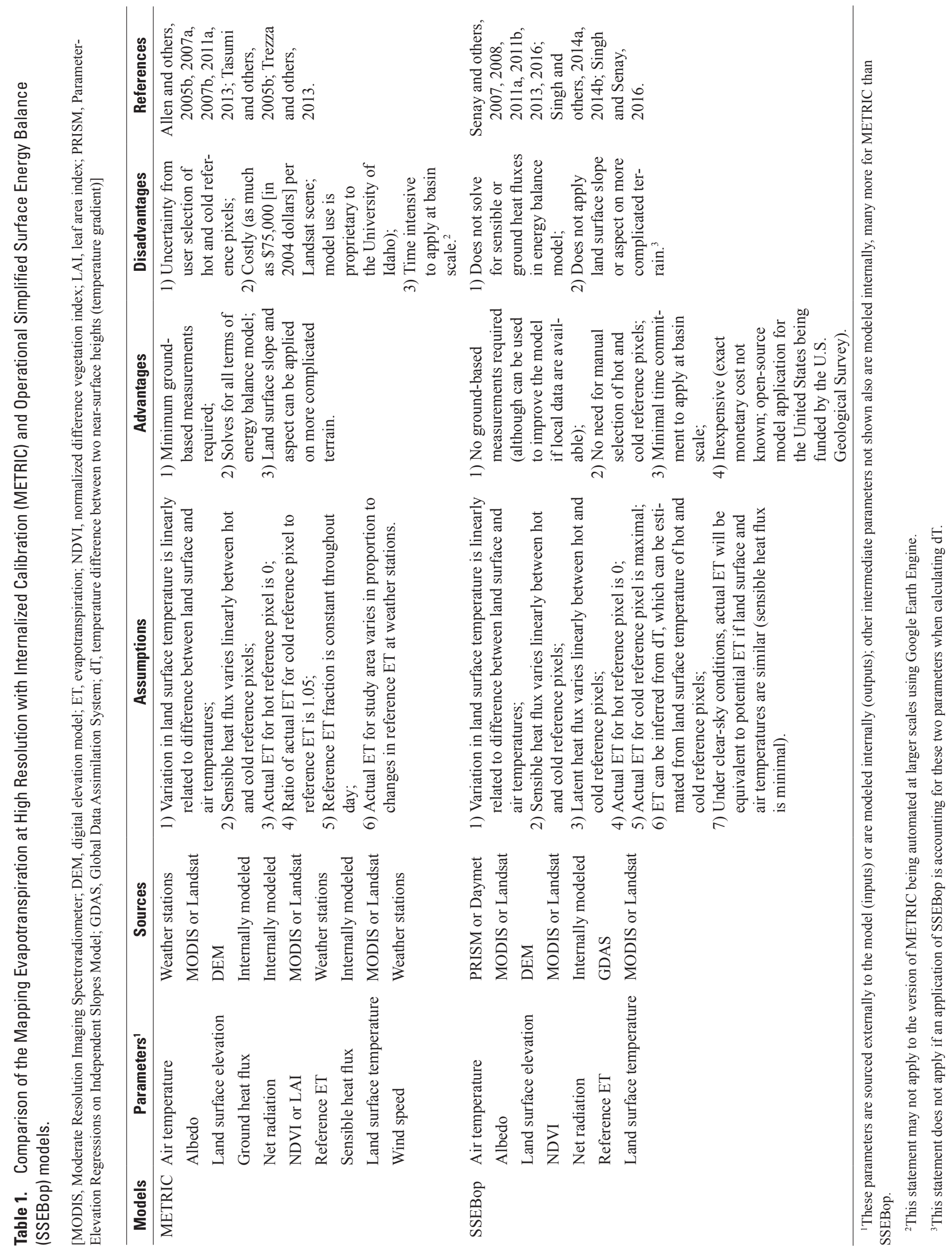


accuracy is possible with the incorporation of ground-based data, no ground-based data are required. The process followed by SSEBop in estimating $E T_{a}$ is relatively simple. Instantaneous or averaged surface temperature is taken from Landsat or MODIS data. Daily, weekly, or monthly air temperature is taken from Daymet data, or ground-based weather data for higher spatial resolution applications at smaller scales. A correction factor can be calculated relating land surface temperature to air temperature under clear-sky conditions for wet, vegetated pixels. A seasonally dynamic but annually static temperature difference under clear-sky conditions for each pixel is calibrated to a dry, bare pixel. Reference ET is calculated with data from gridded weather fields such as those from GDAS, or ground-based weather data for more local applications. Fractional ET is calculated using the idealized hot and cold reference values for each pixel, and estimates of $E T_{a}$ at the desired time scale are calculated by multiplying reference ET by fractional ET. Although some parts of the process necessitate internal calibration, the skill required is greatly reduced.

\section{Implementation of Large-Scale Estimation of Actual Evapotranspiration with Cloud Computing}

Estimation of consumptive water use at large scales is difficult but is a key priority of the U.S. Geological Survey (USGS) and part of the focus of the National Water Census on mapping water use and availability nationally (U.S. Geological Survey, 2007; Alley and others, 2013). The USGS has been developing an objective way to estimate $E T_{a}$ at this scale, but the high spatiotemporal resolution of $E T_{a}$ estimates using Landsat data over large extents takes immense computing power. For example, in the two consumptive water use studies of the Colorado River Basin that used SSEBop (Singh and others, 2014a; Senay and others, 2016), 43 Landsat scenes on multiple dates, each about 1 gigabyte in size, were analyzed. The Colorado River Basin is about 7.5 percent of the area of the conterminous United States, so a continental-scale analysis of consumptive water use might need to process more than 550 scenes on multiple dates throughout the growing season. This processing involves masking clouds from the satellite images, interpolating between dates of satellite images with clear skies, and seamlessly mosaicking the satellite images. Other remote sensing data, such as air temperature, albedo, land surface elevation, and reference ET also require processing prior to inclusion in SSEBop. Because of these geospatial processing needs, an effort at this scale has not occurred.

The size of high spatial resolution satellite imagery can be prohibitive for doing large-scale analyses on an average desktop computer. For example, all the data associated with a Landsat 8 scene downloaded from Earth Explorer (https:// earthexplorer.usgs.gov) are about 1 gigabyte. To download and process data for a great number of scenes on multiple dates is unfeasible at this size, particularly when exploratory analysis is first required. Cloud computing - based on computing resources that are shared over the internet-is providing an opportunity for processing an increasing amount of geospatial "big data" in a decreasing period of time (Yang and others, 2011; Lee and Kang, 2015). For example, although it might take an individual computer 10 hours to process 1 gigabyte of data, cloud computing might apportion that data among 100 (or 1,000) computers, which each take 1 hour (or 1 minute) to process its portion of the data.

Many cloud computing options, such as Amazon Web Services $^{\mathrm{TM}}$, Google Earth Engine ${ }^{\mathrm{TM}}$, IBM Cloud ${ }^{\mathrm{TM}}$, or Microsoft Azure ${ }^{\mathrm{TM}}$, have potential for estimating $E T_{a}$ over larger extents and longer time periods. For example, Google Earth Engine $^{\mathrm{TM}}$, which uses Google's computer infrastructure to process data in parallel on many servers, is already operative in research in the earth sciences (Yu and Gong, 2012). Google Earth Engine ${ }^{\mathrm{TM}}$ has been used to implement METRIC with automated calibration for regional-scale estimates of $E T_{a}$ using Landsat data, with a beta version of a web app presented at Google's 2015 Earth Engine ${ }^{\mathrm{TM}}$ User Summit (J.L. Huntington, Desert Research Institute, oral commun., 2016). The USGS also is using Google Earth Engine ${ }^{\mathrm{TM}}$ to implement SSEBop for estimating $E T_{a}$ in the United States at a continental scale using Landsat data, with a proof-of-concept annual $E T_{a}$ product showcased by the Google Earth Engine ${ }^{\mathrm{TM}}$ Team at the American Geophysical Union's 2016 Fall Meeting (G.B. Senay, U.S. Geological Survey, written commun., 2016). Although estimates of $E T_{a}$ at low spatiotemporal resolution for the contiguous United States are already available (Senay and others, 2013), higher resolution estimates are currently in development.

\section{Summary}

Water resource users and managers have a vested interest in accurately determining consumptive water use, and many approaches have been developed for measuring or estimating actual evapotranspiration $\left(E T_{a}\right)$, which constitutes a large fraction of consumptive water use. The $E T_{a}$ at a site can be measured directly using lysimeters, eddy covariance flux towers, or scintillometers, or indirectly using evaporation pans or Bowen ratio stations, but these direct and indirect measurements of $E T_{a}$ are limited to the sites and times at which they are taken. A simple technique for estimating $E T_{a}$ over larger extents and longer time periods involves the use of crop coefficients, but applying this technique more broadly is difficult because of complications with determining crop types or growth stages from aerial photography or satellite imagery. Research over many years has led to the development of remote sensing methods that are more reproducible and effective in estimating $E T_{a}$. Several remote sensing methods can be used to estimate $E T_{a}^{a}$ at the high spatial resolution of 
agricultural fields and the large extent of river basins-a scale that is useful to water resource managers.

One of the earliest remote sensing methods for estimating $E T_{a}$ was a simplified empirical regression model that estimated $E T_{a}$ from the difference between land surface and air temperatures. This method for estimating $E T_{a}$ is expedient because of its simplicity, and it has been applied successfully in many areas, but applications are limited by a need for sitespecific parameterization that does not allow for transference to new locations. More complex analytical methods have been developed that overcome limitations of this earlier empirical method and are grounded in the theory behind the surface energy balance model, where available energy from shortwave and longwave radiation is balanced by fluxes from the heating of Earth's surface and phase changes of water such as $E T_{a}$. These methods apply an analytical approach to $E T_{a}$ estimation using physically based models of varied complexity that require a combination of ground-based and remote sensing data.

This report, prepared in cooperation with the International Joint Commission, provides an overview of selected remote sensing methods used for estimating water consumed through $E T_{a}$ and focuses on Mapping Evapotranspiration at High Resolution with Internalized Calibration (METRIC) and Operational Simplified Surface Energy Balance (SSEBop), two energy balance models for estimating $E T_{a}$ that are currently applied successfully in the United States. The METRIC model can produce maps of $E T_{a}$ at high spatial resolution (30 meters using Landsat data) for specific areas smaller than several hundred square kilometers in extent, an improvement in practice over methods used more generally at larger scales. This method has been applied for many purposes, including planning of water resources, modeling of watershed hydrology, mapping of water use by riparian vegetation, monitoring of water rights compliance, evaluation of aquifer depletion from pumpage, and assessment of irrigation performance. Similar to METRIC, SSEBop is another remote sensing method that applies the surface energy balance model to estimate $E T_{a}$, and applications of this method also have had many purposes, including drought monitoring and famine early warning in regions with sparse ground-based data, mapping of water use by different land cover classes, and estimation of $E T_{a}$ in the United States at regional to continental scales. The SSEBop model has been used to produce maps of $E T_{a}$ over very large extents (the conterminous United States) using lower spatial resolution (1 kilometer) Moderate Resolution Imaging Spectroradiometer (MODIS) data. Unlike METRIC, SSEBop requires less parameterization of the energy balance model, making for simpler application over larger extents, and does not have the same requirements for finely resolved ground-based data such as hourly weather information.

The METRIC and SSEBop models each have been shown to estimate $E T_{a}$ with acceptable accuracies in many applications. A robust remote sensing method for estimating $E T_{a}$, METRIC has been applied successfully in the United States and internationally. The SSEBop model largely has been used to estimate $E T_{a}$ in the United States. The METRIC and SSEBop models have many similarities, including their theoretical grounding in the surface energy balance model and that they can incorporate low (1 kilometer) and high (30 meter) spatial resolution data from MODIS and Landsat; however, they have important differences in data requirements, ease of implementation, and cost.

The METRIC model has shown greater accuracy at estimating $E T_{a}$ than simpler techniques that use crop coefficients or vegetation indices exclusively, and also removes the need to know crop type and growth stage. The model can detect reductions in $E T_{a}$ from water shortages, soil salinity, and frozen soil, and can detect evaporative losses from bare soil. In addition, many studies validating METRIC estimates of $E T_{a}$ against measurements from lysimeters have shown model accuracies on daily to seasonal time scales ranging from 85 to 95 percent. The METRIC model is accurate, but the greater complexity of METRIC results in greater data requirements, and the internalized calibration of METRIC leads to greater skill required for implementation. In contrast, SSEBop is a simpler model, having reduced data requirements and greater ease of implementation without a substantial loss of accuracy in estimating $E T_{a}$. Model accuracies ranging from 80 to 95 percent on daily to annual time scales have been shown in numerous studies that validated $E T_{a}$ estimates from SSEBop against eddy covariance measurements.

Estimation of consumptive water use at large scales is difficult but is a key priority of the U.S. Geological Survey (USGS) and part of the focus of the National Water Census on mapping water use and availability nationally. The USGS has been developing an objective way to estimate $E T_{a}$ at this scale, but the high spatiotemporal resolution of $E T_{a}$ estimates using Landsat data over large extents takes immense computing power. Cloud computing is providing an opportunity for processing an increasing amount of geospatial "big data" in a decreasing period of time. For example, Google Earth Engi$\mathrm{ne}^{\mathrm{TM}}$ has been used to implement METRIC with automated calibration for regional-scale estimates of $E T_{a}$ using Landsat data. The USGS also is using Google Earth Engine ${ }^{\mathrm{TM}}$ to implement SSEBop for estimating $E T_{a}$ in the United States at a continental scale using Landsat data. Although estimates of $E T_{a}$ at low spatiotemporal resolution for the contiguous United States are already available, higher resolution estimates are currently in development.

\section{Acknowledgments}

We thank Sean Lawlor and Dr. Gabriel Senay for providing reviews that helped improve this report. 


\section{References Cited}

Allen, R.G., 2000, Using the FAO-56 dual crop coefficient method over an irrigated region as part of an evapotranspiration intercomparison study: Journal of Hydrology, v. 229, no. 1-2, p. 27-41. [Also available at https://doi.org/10.1016/ S0022-1694(99)00194-8.]

Allen, R.G., Burnett, B., Kramber, W., Huntington, J., Kjaersgaard, J., Kilic, A., Kelly, C., and Trezza, R., 2013, Automated calibration of the METRIC-Landsat Evapotranspiration Process: Journal of the American Water Resources Association, v. 49, no. 3, p. 563-576. [Also available at http://dx.doi.org/10.1111/jawr.12056.]

Allen, R.G., Irmak, A., Trezza, R., Hendrickx, J.M.H., Bastiaanssen, W., and Kjaersgaard, J., 2011a, Satellite-based ET estimation in agriculture using SEBAL and METRIC: Hydrological Processes, v. 25, no. 26, p. 4011-4027. [Also available at http://dx.doi.org/10.1002/hyp.8408.]

Allen, R.G., Pereira, L.S., Howell, T.A., and Jensen, M.E., 2011 b, Evapotranspiration information reporting-I. Factors governing measurement accuracy: Agricultural Water Management, v. 98, no. 6, p. 899-920. [Also available at https://doi.org/10.1016/j.agwat.2010.12.015.]

Allen, R.G., Pereira, L., Raes, D., and Smith, M., 1998, Crop evapotranspiration-Guidelines for computing crop water requirements: Food and Agriculture Organization of the United Nations Irrigation and Drainage Paper 56. [Also available at http://www.fao.org/docrep/X0490E/X0490E00. htm.]

Allen, R.G., Pereira, L.S., Smith, M., Raes, D., and Wright, J.L., 2005a, FAO-56 dual crop coefficient method for estimating evaporation from soil and application extensions: Journal of Irrigation and Drainage Engineering, v. 131, no. 1, p. 2-13. [Also available at https://doi.org/10.1061/ (ASCE)0733-9437(2005)131:1(2).]

Allen, R.G., Tasumi, M., Morse, A., and Trezza, R., 2005b, A Landsat-based energy balance and evapotranspiration model in Western US water rights regulation and planning: Irrigation and Drainage Systems, v. 19, no. 3, p. 251-268. [Also available at http://dx.doi.org/10.1007/s10795-005-5187-z.]

Allen, R.G., Tasumi, M., Morse, A., Trezza, R., Wright, J.L., Bastiaanssen, W., Kramber, W., Lorite, I., and Robison, C.W., 2007a, Satellite-based energy balance for Mapping Evapotranspiration with Internalized Calibration (METRIC) - Applications: Journal of Irrigation and Drainage Engineering, v. 133, no. 4, p. 395-406. [Also available at https://doi.org/10.1061/(ASCE)07339437(2007)133:4(395).]
Allen, R.G., Tasumi, M., and Trezza, R., 2007b, Satellitebased energy balance for Mapping Evapotranspiration with Internalized Calibration (METRIC)—Model: Journal of Irrigation and Drainage Engineering, v. 133, no. 4, p. 380-394. [Also available at https://doi.org/10.1061/ (ASCE)0733-9437(2007)133:4(380).]

Alley, W.M., Evenson, E.J., Barber, N.L., Bruce, B.W., Dennehy, K.F., Freeman, M.C., Freeman, W.O., Fischer, J.M., Hughes, W.B., Kennen, J.G., Kiang, J.E., Maloney, K.O., Musgrove, M., Ralston, B., Tessler, S., and Verdin, J.P., 2013, Progress toward establishing a national assessment of water availability and use: U.S. Geological Survey Circular 1384, 34 p.. [Also available at http://pubs.usgs.gov/ circ/1384.]

American Society of Civil Engineers, 2005, The ASCE standardized reference evapotranspiration equation: Environmental and Water Resources Institute of the American Society of Civil Engineers Task Committee on Standardization of Reference Evapotranspiration Final Report, 216 p.

Anderson, M.C., Norman, J.M., Diak, G.R., Kustas, W.P., and Mecikalski, J.R., 1997, A two-source time-integrated model for estimating surface fluxes using thermal infrared remote sensing: Remote Sensing of Environment, v. 60, no. 2, p. 195-216. [Also available at https://doi.org/10.1016/S00344257(96)00215-5.]

Bastiaanssen, W.G.M., 1995, Regionalization of surface flux densities and moisture indicators in composite terrain-A remote sensing approach under clear skies in Mediterranean climates: Wageningen, The Netherlands, Wageningen University, Ph.D. dissertation.

Bastiaanssen, W.G.M., 2000, SEBAL-based sensible and latent heat fluxes in the irrigated Gediz Basin, Turkey: Journal of Hydrology, v. 229, no. 1-2, p. 87-100. [Also available at https://doi.org/10.1016/S0022-1694(99)00202-4.]

Bastiaanssen, W.G.M., Menenti, M., Feddes, R.A., and Holtslag, A.A.M., 1998a, A remote sensing surface energy balance algorithm for land (SEBAL) - 1. Formulation: Journal of Hydrology, v. 212-213, p. 198-212. [Also available at https://doi.org/10.1016/S0022-1694(98)00253-4.]

Bastiaanssen, W.G.M., Noordman, E., Pelgrum, H., Davids, G., Thoreson, B., and Allen, R., 2005, SEBAL model with remotely sensed data to improve water-resources management under actual field conditions: Journal of Irrigation and Drainage Engineering, v. 131, no. 1, p. 85-93. [Also available at https://doi.org/10.1061/(ASCE)07339437(2005)131:1(85).] 
Bastiaanssen, W.G.M., Pelgrum, H., Wang, J., Ma, Y., Moreno, J.F., Roerink, G.J., and van der Wal, T., 1998b, A remote sensing surface energy balance algorithm for land (SEBAL) - Part 2. Validation: Journal of Hydrology, v. 212-213, p. 213-229. [Also available at https://doi. org/10.1016/S0022-1694(98)00254-6.]

Biggs, T.W., Petropoulos, G.P., Velpuri, N.M., Marshall, M., Glenn, E.P., Nagler, P., and Messina, A., 2015, Remote sensing of actual evapotranspiration from cropland, chap. 3 of Thenkabail, P.S., ed., Remote sensing of water resources, disasters, and urban studies: CRC Press, p. 59-99. [Also available at https://pubs.er.usgs.gov/publication/70176490.]

Carlson, T.N., and Buffum, M.J., 1989, On estimating total daily evapotranspiration from remote surface temperature measurements: Remote Sensing of Environment, v. 29, no. 2, p. 197-207. [Also available at https://doi. org/10.1016/0034-4257(89)90027-8.]

Carr, J.E., Chase, E.B., Paulson, R.W., and Moody, D.W., 1990, National water summary 1987-Hydrologic events and water supply and use: U.S. Geological Survey Water Supply Paper 2350, 567 p.. [Also available at http://pubs. er.usgs.gov/publication/wsp2350.]

Chen, M., Senay, G.B., Singh, R.K., and Verdin, J.P., 2016, Uncertainty analysis of the Operational Simplified Surface Energy Balance (SSEBop) model at multiple flux tower sites: Journal of Hydrology, v. 536, p. 384-399. [Also available at https://doi.org/10.1016/j.jhydrol.2016.02.026.]

Choudhury, B.J., Ahmed, N.U., Idso, S.B., Reginato, R.J., and Daughtry, C.S.T., 1994, Relations between evaporation coefficients and vegetation indices studied by model simulations: Remote Sensing of Environment, v. 50, no. 1, p. 1-17. [Also available at https://doi.org/10.1016/00344257(94)90090-6.]

French, A.N., Hunsaker, D.J., and Thorp, K.R., 2015, Remote sensing of evapotranspiration over cotton using the TSEB and METRIC energy balance models: Remote Sensing of Environment, v. 158, p. 281-294. [Also available at https:// doi.org/10.1016/j.rse.2014.11.003.]

Fritschen, L.J., 1965, Accuracy of evapotranspiration determinations by the Bowen ratio method: Hydrological Sciences Journal, v. 10, no. 2, p. 38-48. [Also available at http:// dx.doi.org/10.1080/02626666509493388.]

Gowda, P.H., Chavez, J.L., Colaizzi, P.D., Evett, S.R., Howell, T.A., and Tolk, J.A., 2008a, ET mapping for agricultural water management - Present status and challenges: Irrigation Science, v. 26, no. 3, p. 223-237. [Also available at http://dx.doi.org/10.1007/s00271-007-0088-6.]
Gowda, P.H., Chávez, J.L., Howell, T.A., Marek, T.H., and New, L.L., 2008b, Surface energy balance based evapotranspiration mapping in the Texas High Plains: Sensors, v. 8, no. 8, p. 5186-5201. [Also available at http://dx.doi. org/10.3390/s8085186.]

Gowda, P.H., Senay, G.B., Howell, T.A., and Marek, T.H., 2009, Lysimetric evaluation of simplified surface energy balance approach in the Texas High Plains: Applied Engineering in Agriculture, v. 25, no. 5, p. 665-669. [Also available at https://pubs.er.usgs.gov/publication/70043493.]

Helsel, D.R., and Hirsch, R.M., 2002, Statistical methods in water resources: U.S. Geological Survey Techniques of Water-Resources Investigations, book 4, chap. A3, 522 p. [Also available at http://water.usgs.gov/pubs/twri/twri4a3.]

Idso, S.B., Schmugge, T.J., Jackson, R.D., and Reginato, R.J., 1975, The utility of surface temperature measurements for the remote sensing of surface soil water status: Journal of Geophysical Research, v. 80, no. 21, p. 3044-3049. [Also available at http://dx.doi.org/10.1029/JC080i021p03044.]

Jackson, R.D., Reginato, R.J., and Idso, S.B., 1977, Wheat canopy temperature - A practical tool for evaluating water requirements: Water Resources Research, v. 13, no. 3, p. 651-656. [Also available at http://dx.doi.org/10.1029/ WR013i003p00651.]

Khan, S.I., Chang, N.-B., Hong, Y., Xue, X., and Zhang, Y., 2015, Remote sensing technologies for multiscale hydrological studies - Advances and perspectives, chap. 1 of Thenkabail, P.S., ed., Remote sensing of water resources, disasters, and urban studies: CRC Press, p. 3-21. [Also available at https://pubs.er.usgs.gov/publication/70176490.]

Lee, J.-G., and Kang, M., 2015, Geospatial big data-Challenges and opportunities: Big Data Research, v. 2, no. 2, p. 74-81. [Also available at https://doi.org/10.1016/j. bdr.2015.01.003.]

Li, Z.-L., Tang, R., Wan, Z., Bi, Y., Zhou, C., Tang, B., Yan, G., and Zhang, X., 2009, A review of current methodologies for regional evapotranspiration estimation from remotely sensed data: Sensors, v. 9, no. 5, p. 3801-3853. [Also available at http://dx.doi.org/10.3390/s90503801.]

Liou, Y.-A., and Kar, S.K., 2014, Evapotranspiration estimation with remote sensing and various surface energy balance algorithms - A review: Energies, v. 7, no. 5, p. 2821-2849. [Also available at http://dx.doi.org/10.3390/en7052821.]

Long, D., and Singh, V.P., 2013, Assessing the impact of endmember selection on the accuracy of satellite-based spatial variability models for actual evapotranspiration estimation: Water Resources Research, v. 49, no. 5, p. 2601-2618. [Also available at http://dx.doi.org/10.1002/wrcr.20208.] 
Maupin, M.A., Kenny, J.F., Hutson, S.S., Lovelace, J.K., Barber, N.L., and Linsey, K.S., 2014, Estimated use of water in the United States in 2010: U.S. Geological Survey Circular 1405, 56 p.. [Also available at http://pubs.usgs.gov/ circ/1405.]

Mecikalski, J.R., Diak, G.R., Anderson, M.C., and Norman, J.M., 1999, Estimating fluxes on continental scales using remotely sensed data in an Atmospheric-Land Exchange Model: Journal of Applied Meteorology, v. 38, no. 9, p. 1352-1369. [Also available at https://doi.org/10.1175/15200450(1999)038\%3C1352:EFOCSU\%3E2.0.CO;2.]

Meijninger, W.M.L., Green, A.E., Hartogensis, O.K., Kohsiek, W., Hoedjes, J.C.B., Zuurbier, R.M., and De Bruin, H.A.R., 2002, Determination of area-averaged water vapour fluxes with large aperture and radio wave scintillometers over a heterogeneous surface-Flevoland field experiment: Boundary-Layer Meteorology, v. 105, no. 1, p. 63-83. [Also available at http://dx.doi.org/10.1023/A:1019683616097.]

Morton, C.G., Huntington, J.L., Pohll, G.M., Allen, R.G., McGwire, K.C., and Bassett, S.D., 2013, Assessing calibration uncertainty and automation for estimating evapotranspiration from agricultural areas using METRIC: Journal of the American Water Resources Association, v. 49, no. 3, p. 549-562. [Also available at http://dx.doi.org/10.1111/ jawr.12054.]

Mu, Q., Heinsch, F.A., Zhao, M., and Running, S.W., 2007, Development of a global evapotranspiration algorithm based on MODIS and global meteorology data: Remote Sensing of Environment, v. 111, no. 4, p. 519-536. [Also available at https://doi.org/10.1016/j.rse.2007.04.015.]

Nash, J.E., and Sutcliffe, J.V., 1970, River flow forecasting through conceptual models-Part 1. A discussion of principles: Journal of Hydrology, v. 10, no. 3, p. 282-290. [Also available at https://doi.org/10.1016/0022-1694(70)90255-6.]

Nieuwenhuis, G.J.A., Smidt, E.H., and Thunnissen, H.A.M., 1985, Estimation of regional evapotranspiration of arable crops from thermal infrared images: International Journal of Remote Sensing, v. 6, no. 8, p. 1319-1334. [Also available at http://www.tandfonline.com/doi/ abs/10.1080/01431168508948282.]

Norman, J.M., Kustas, W.P., and Humes, K.S., 1995, Source approach for estimating soil and vegetation energy fluxes in observations of directional radiometric surface temperature: Agricultural and Forest Meteorology, v. 77, no. 3-4, p. 263-293. [Also available at https://doi. org/10.1016/0168-1923(95)02265-Y.]
Norman, J.M., Kustas, W.P., Prueger, J.H., and Diak, G.R., 2000, Surface flux estimation using radiometric temperature-A dual-temperature-difference method to minimize measurement errors: Water Resources Research, v. 36, no. 8, p. 2263-2274. [Also available at http://dx.doi. org/10.1029/2000WR900033.]

Pruitt, W.O., and Angus, D.E., 1960, Large weighing lysimeter for measuring evapotranspiration: Transactions of the ASABE, v. 3, no. 2, p. 13-15. [Also available at http:// dx.doi.org/10.13031/2013.41105.]

Qiu, G.Y., Yano, T., and Momii, K., 1998, An improved methodology to measure evaporation from bare soil based on comparison of surface temperature with a dry soil surface: Journal of Hydrology, v. 210, no. 1-4, p. 93-105. [Also available at https://doi.org/10.1016/S0022-1694(98)00174-7.]

Roerink, G.J., Su, Z., and Menenti, M., 2000, S-SEBI-A simple remote sensing algorithm to estimate the surface energy balance: Physics and Chemistry of the Earth, Part B: Hydrology, Oceans and Atmosphere, v. 25, no. 2, p. 147-157. [Also available at https://doi.org/10.1016/S14641909(99)00128-8.]

Ruhoff, A.L., Paz, A.R., Collischonn, W., Aragao, L.E.O.C., Rocha, H.R., and Malhi, Y.S., 2012, A MODIS-based energy balance to estimate evapotranspiration for clearsky days in Brazilian tropical savannas: Remote Sensing, v. 4, no. 3, p. 703-725. [Also available at http://dx.doi. org/10.3390/rs4030703.]

Santos, C., Lorite, I.J., Tasumi, M., Allen, R.G., and Fereres, E., 2008, Integrating satellite-based evapotranspiration with simulation models for irrigation management at the scheme level: Irrigation Science, v. 26, no. 3, p. 277-288. [Also available at http://dx.doi.org/10.1007/s00271-007-0093-9.]

Seguin, B., Courault, D., and Guérif, M., 1994, Surface temperature and evapotranspiration-Application of local scale methods to regional scales using satellite data: Remote Sensing of Environment, v. 49, no. 3, p. 287-295. [Also available at https://doi.org/10.1016/0034-4257(94)90023-X.]

Seguin, B., and Itier, B., 1983, Using midday surface temperature to estimate daily evaporation from satellite thermal IR data: International Journal of Remote Sensing, v. 4, no. 2, p. 371-383. [Also available at http://dx.doi. org/10.1080/01431168308948554.]

Senay, G.B., Bohms, S., Singh, R.K., Gowda, P.H., Velpuri, N.M., Alemu, H., and Verdin, J.P., 2013, Operational evapotranspiration mapping using remote sensing and weather datasets-A new parameterization for the SSEB approach: Journal of the American Water Resources Association, v. 49, no. 3, p. 577-591. [Also available at http://dx.doi. org/10.1111/jawr.12057.] 
Senay, G.B., Budde, M.E., and Verdin, J.P., 2011a, Enhancing the Simplified Surface Energy Balance (SSEB) approach for estimating landscape ET - Validation with the METRIC model: Agricultural Water Management, v. 98, no. 4, p. 606-618. [Also available at https://doi.org/10.1016/j. agwat.2010.10.014.]

Senay, G.B., Budde, M., Verdin, J.P., and Melesse, A.M., 2007, A coupled remote sensing and simplified surface energy balance approach to estimate actual evapotranspiration from irrigated fields: Sensors, v. 7, no. 6, p. 979-1000. [Also available at http://dx.doi.org/10.3390/s7060979.]

Senay, G.B., Friedrichs, M., Singh, R.K., and Velpuri, N.M., 2016, Evaluating Landsat 8 evapotranspiration for water use mapping in the Colorado River Basin: Remote Sensing of Environment, v. 185, p. 171-185. [Also available at https:// doi.org/10.1016/j.rse.2015.12.043.]

Senay, G.B., Leake, S., Nagler, P.L., Artan, G., Dickinson, J., Cordova, J.T., and Glenn, E.P., 2011b, Estimating basin scale evapotranspiration (ET) by water balance and remote sensing methods: Hydrological Processes, v. 25, no. 26, p. 4037-4049. [Also available at http://dx.doi.org/10.1002/ hyp.8379.]

Senay, G.B., Verdin, J.P., Lietzow, R., and Melesse, A.M., 2008, Global daily reference evapotranspiration modeling and evaluation: Journal of the American Water Resources Association, v. 44, no. 4, p. 969-979. [Also available at http://dx.doi.org/10.1111/j.1752-1688.2008.00195.x.]

Singh, R.K., and Senay, G.B., 2016, Comparison of four different energy balance models for estimating evapotranspiration in the Midwestern United States: Water, v. 8, no. 1, 9 p.. [Also available at http://dx.doi.org/10.3390/w8010009.]

Singh, R.K., Senay, G.B., Velpuri, N.M., Bohms, S., Scott, R.L., and Verdin, J.P., 2014a, Actual evapotranspiration (water use) assessment of the Colorado River Basin at the Landsat resolution using the Operational Simplified Surface Energy Balance Model: Remote Sensing, v. 6, no. 1, p. 233 256. [Also available at https://doi.org/10.3390/rs6010233.]

Singh, R.K., Senay, G.B., Velpuri, N.M., Bohms, S., and Verdin, J.P., 2014b, On the downscaling of actual evapotranspiration maps based on combination of MODIS and Landsat-based actual evapotranspiration estimates: Remote Sensing, v. 6, no. 11, p. 10483-10509. [Also available at http://dx.doi.org/10.3390/rs61110483.]

Snyder, R.L., 1992, Equation for evaporation pan to evapotranspiration conversions: Journal of Irrigation and Drainage Engineering, v. 118, no. 6, p. 977-980. [Also available at https://doi.org/10.1061/(ASCE)07339437(1992)118:6(977).]
Su, Z., 2002, The Surface Energy Balance System (SEBS) for estimation of turbulent heat fluxes: Hydrology and Earth System Sciences, v. 6, no. 1, p. 85-100. [Also available at http://dx.doi.org/10.5194/hess-6-85-2002.]

Swinbank, W.C., 1951, The measurement of vertical transfer of heat and water vapor by eddies in the lower atmosphere: Journal of Meteorology, v. 8, no. 3, p. 135-145. [Also available at https://doi.org/10.1175/1520-0469(1951)008\%3C01 35:TMOVTO\%3E2.0.CO;2.]

Taconet, O., Carlson, T., Bernard, R., and Vidal-Madjar, D., 1986, Evaluation of a surface/vegetation parameterization using satellite measurements of surface temperature: Journal of Climate and Applied Meteorology, v. 25, no. 11, p. 1752-1767. [Also available at https://doi.org/10.1175/15200450(1986)025\%3C1752:EOASPU\%3E2.0.CO;2.]

Tasumi, M., 2003, Progress in operational estimation of regional evapotranspiration using satellite imagery: Moscow, Idaho, University of Idaho, Ph.D. dissertation.

Tasumi, M., Allen, R.G., Trezza, R., and Wright, J.L., 2005a, Satellite-based energy balance to assess within-population variance of crop coefficient curves: Journal of Irrigation and Drainage Engineering, v. 131, no. 1, p. 94-109. [Also available at https://doi.org/10.1061/(ASCE)07339437(2005)131:1(94).]

Tasumi, M., Trezza, R., Allen, R.G., and Wright, J.L., 2005b, Operational aspects of satellite-based energy balance models for irrigated crops in the semi-arid U.S.: Irrigation and Drainage Systems, v. 19, no. 3-4, p. 355-376. [Also available at http://dx.doi.org/10.1007/s10795-005-8138-9.]

Thornton, P.E., Running, S.W., and White, M.A., 1997, Generating surfaces of daily meteorological variables over large regions of complex terrain: Journal of Hydrology, v. 190, no. 3-4, p. 214-251. [Also available at https://doi. org/10.1016/S0022-1694(96)03128-9.]

Timmermans, W.J., Kustas, W.P., Anderson, M.C., and French, A.N., 2007, An intercomparison of the Surface Energy Balance Algorithm for Land (SEBAL) and the Two-Source Energy Balance (TSEB) modeling schemes: Remote Sensing of Environment, v. 108, no. 4, p. 369-384. [Also available at https://doi.org/10.1016/j.rse.2006.11.028.]

Trezza, R., Allen, R.G., and Tasumi, M., 2013, Estimation of actual evapotranspiration along the Middle Rio Grande of New Mexico using MODIS and Landsat imagery with the METRIC model: Remote Sensing, v. 5, no. 10, p. 5397-5423. [Also available at http://dx.doi.org/10.3390/ rs5105397.]

U.S. Geological Survey, 2007, Facing tomorrow's challenges-U.S. Geological Survey science in the decade 2007-2017: U.S. Geological Survey Circular 1309, 70 p.. [Also available at https://pubs.usgs.gov/circ/2007/1309.] 
Vörösmarty, C.J., Green, P., Salisbury, J., and Lammers, R.B., 2000, Global water resources - Vulnerability from climate change and population growth: Science, v. 289 , no. 5477 , p. 284-288. [Also available at http://dx.doi.org/10.1126/science.289.5477.284.]

Yang, C., Goodchild, M., Huang, Q., Nebert, D., Raskin, R., Xu, Y., Bambacus, M., and Fay, D., 2011, Spatial cloud computing - How can the geospatial sciences use and help shape cloud computing?: International Journal of Digital Earth, v. 4, no. 4, p. 305-329. [Also available at http:// dx.doi.org/10.1080/17538947.2011.587547.]

Yang, Y., Shang, S., and Jiang, L., 2012, Remote sensing temporal and spatial patterns of evapotranspiration and the responses to water management in a large irrigation district of North China: Agricultural and Forest Meteorology, v. 164, p. 112-122. [Also available at https://doi.org/10.1016/j. agrformet.2012.05.011.]

Yang, Y., Su, H., Zhang, R., Tian, J., and Li, L., 2015, An enhanced two-source evapotranspiration model for land (ETEML) - Algorithm and evaluation: Remote Sensing of Environment, v. 168, p. 54-65. [Also available at https:// doi.org/10.1016/j.rse.2015.06.020.]

Yu, L., and Gong, P., 2012, Google Earth as a virtual globe tool for Earth science applications at the global scaleProgress and perspectives: International Journal of Remote Sensing, v. 33, no. 12, p. 3966-3986. [Also available at http://dx.doi.org/10.1080/01431161.2011.636081.] 
For additional information concerning this publication, contact: Director, USGS Wyoming-Montana Water Science Center 3162 Bozeman Avenue Helena, MT 59601

(406) 457-5900

Or visit the Wyoming-Montana Water Science Center website at: https://wy-mt.water.usgs.gov

Publishing support provided by: Rolla Publishing Service Center 



\section{$\frac{\mathbb{2}}{3}$}

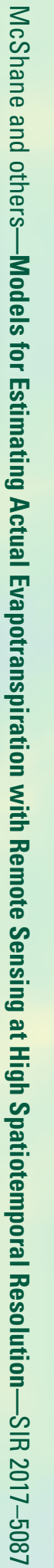

